\title{
A DeCADe Of Ruby from MOZambiQue: A ReVIEW
}

Wim Vertriest and Sudarat Saeseaw

In less than a decade, Mozambique has become the world's most productive source for gem-quality ruby. Since the discovery in 2009, GIA has followed these deposits from the front lines, collecting data in the field and in the laboratory. The development of the deposit in Montepuez has been extremely interesting, with different players involved and different types of material unearthed. This article provides a summary and overview of the current knowledge about Mozambican ruby, including the history of mining and the market impact, as well as a comprehensive gemological characterization and discussion of the most common treatments applied to the stones. Much of the information in this article is based on the authors' observations in the field and market as well as several publications (Pardieu et al., 2009, 2013, 2015; Saeseaw et al., 2018).

M ozambique lies in southeastern Africa, with the city of Maputo as its capital. It shares borders with Tanzania to the north, Malawi and Zambia to the northwest, Zimbabwe to the west, and Swaziland and South Africa to the south. In the east, Mozambique is separated from Madagascar by the Mozambique Channel, which is part of the Indian Ocean. Many of these countries are known producers of gem corundum. Mozambique joined this club of ruby sources only in the last decade, a mere fraction of its long history.

Around 2,000 years ago, Bantu tribes settled in what is now Mozambique. In the eleventh century, traders from the northern shores arrived and set up trading posts. These were mainly Arab, Persian, and Somali merchants who merged their own customs with those of the local Bantu, leading to the development of the Swahili culture along the eastern coast of Africa.

In 1498, Vasco da Gama was the first European to arrive in Mozambique, en route to India. He encountered the Arab merchant ruler Mussa Bin Bique, whose name was given to the area. Vasco da Gama's arrival started the Portuguese influence in the East African country, which lasted until Mozambique gained independence in 1975. This independence sparked a civil war that tore the country apart until the mid-1990s, when its first elections with multiple

See end of article for About the Authors and Acknowledgments.

Gems \& Gemology, Vol. 55, No. 2, pp. 162-183,

http://dx.doi.org/10.5741/GEMS.55.2.162

(C) 2019 Gemological Institute of America parties were held. Since these elections, the country has been relatively stable, although insurgent groups are still active.

The country's population of more than 29 million is largely Christian, with a significant number who follow Islam or traditional animistic beliefs. Portuguese remains the official language, though many

\section{In Brief}

- Mozambique entered the ruby market in 2009 and quickly became one of the most important producers on a global level.

- Small-scale artisanal miners and large companies have both played an important role in the rise and development of the Mozambican ruby mines and market.

- The Montepuez deposits produce rubies with different appearances. Two main types can be distinguished: "Maninge Nice"-type and Mugloto-type.

- Mozambican rubies are routinely treated, depending on the starting material. The goal is to improve either the color or the clarity.

people still speak local languages. Since the early 2000s, Mozambique has seen some of the world's largest gains in GDP, but it is still among the poorest and least developed countries. Most of the population and economic power are in the southern provinces.

Mozambique's economy is heavily focused on mineral resources and agriculture. More than $80 \%$ of the population is involved in agriculture. 


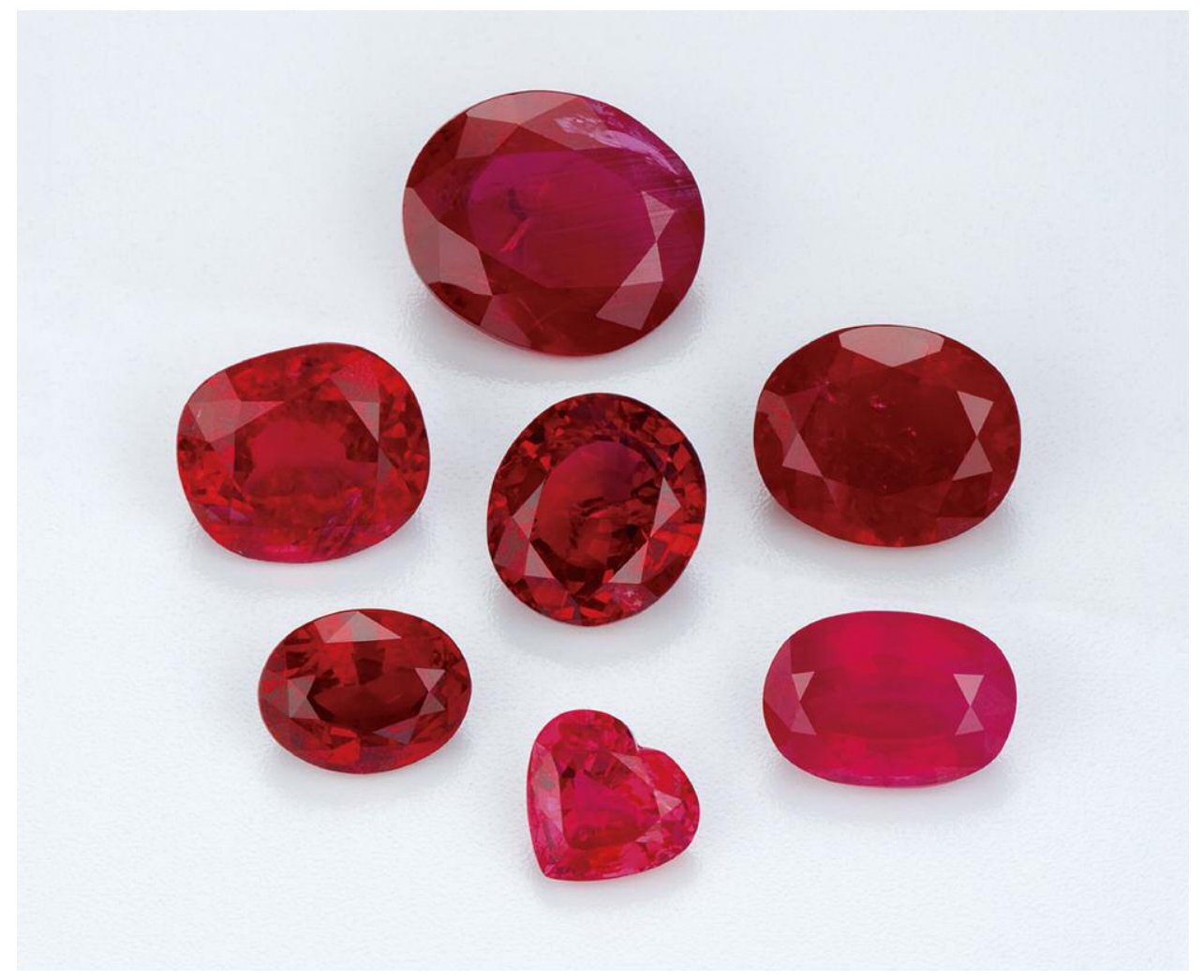

Figure 1. This photo shows a variety of rubies from various areas in northern Mozambique (Niassa and Montepuez) that were mined in 2009-2010. It includes untreated and heated stones, weighing between 1.07 and 4.62 ct. Photo by Robert Weldon/GIA. Courtesy of Tommy Wu, Shire Trading Ltd.

Shrimp, timber, cashews, coconuts, tea, and tobacco are some of the main exports. Tourism is developing rapidly but remains small compared to other industries.

The mining sector includes building stones and granulates (marble and granite), industrial minerals (bentonite and sand), and metallic ores (gold, titanium, beryllium, tantalum, and bauxite). The country is also an important coal producer. Newly discovered offshore gas fields in northern Mozambique are generating considerable interest, though development is hindered by falling prices for oil and natural gas.

\section{HISTORY OF RUBY IN MOZAMBIQUE}

Mozambique holds large reserves of gemstones. Aquamarine and morganite are mined in Zambezia Province, while copper-bearing tourmaline is found at the Alto Ligonha field in Nampula Province (Rondeau and Delaunay, 2007; Laurs et al., 2008). Garnets and tourmaline varieties are found throughout the country, though most of the production is focused in the western and northern regions (Shigley et al., 2010; Sangsawong et al., 2016). The area around Ocua in Nampula produced pink spinel for a period in 2016 (Vertriest and Pardieu, 2016).
Early Discoveries. Corundum has been documented in Mozambique ever since Europeans first colonized the land. Although it was not discovered at the time, the presence of gem ruby (see figure 1) was suggested by the high volumes of Cr-bearing corundum (Lächelt, 2004).

The earliest mention of Mozambican ruby in the gemological literature came in 1991, when Gems Gemology reported cabochon-grade rough samples at the Tucson gem shows. It was described as similar to some Tanzanian material (Koivula and Kammerling, 1991).

Ruby from Northwest Mozambique. The first confirmed sources of gem-quality ruby were found in northern Mozambique in the Niassa National Reserve in 2008. Near Ruambeze, in Cabo Delgado Province, cabochon-grade rubies were reportedly discovered in the early 1990s, according to officials from the Lichinga mining office. This deposit reportedly produced the cabochon-grade material reported in $G \uplus G$ in 1991 . The material was heavily fractured and often contained considerable iron staining, obscuring the bodycolor (figure 2). Mining never really took off in this area due to the remote location and the mediocre quality (Pardieu et al., 2009a,b). 


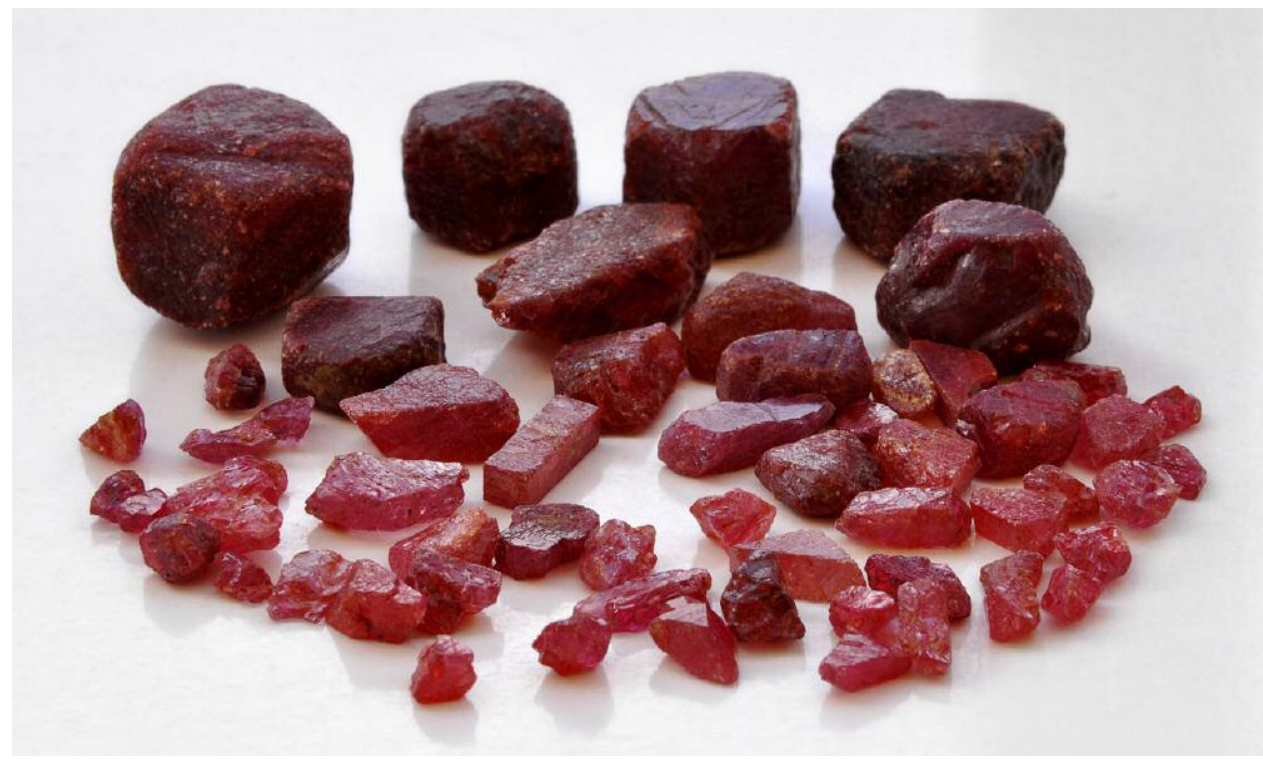

Figure 2. Rubies reportedly from the Ruambeze deposit obtained from a gem dealer in Lichinga. Photo by J.B. Senoble, September 2009.

The first facet-grade ruby was mined near the village of M'sawize, also located in the Niassa National Reserve. Artisanal miners worked a deposit about 40 $\mathrm{km}$ east of the village. It is assumed that this deposit was discovered in September 2008, when it began to attract large crowds of artisanal miners and buyers (Pardieu et al., 2009a,b). The deposit was closed to artisanal miners in 2009, but some mining licenses were granted to war veterans who attempted to further develop this deposit (V. Pardieu, pers. comm., 2019). According to some people, rubies from Niassa were already locally known for several years but had been overshadowed by the Winza deposit in Tanza- nia and Andilamena in Madagascar (Pardieu et al., 2009a,b).

The material ranges from pink to dark red, and faceted stones over 10 carats are produced (figure 3). However, the majority of this material would still require enhancement to solve clarity issues related to the fractures. This could be done by glass filling or flux healing.

Production in M'sawize was mostly abandoned in July and August 2009 due to the onset of the dry season and law enforcement efforts to control the illegal mining operations. Fortunately, another ruby deposit emerged.

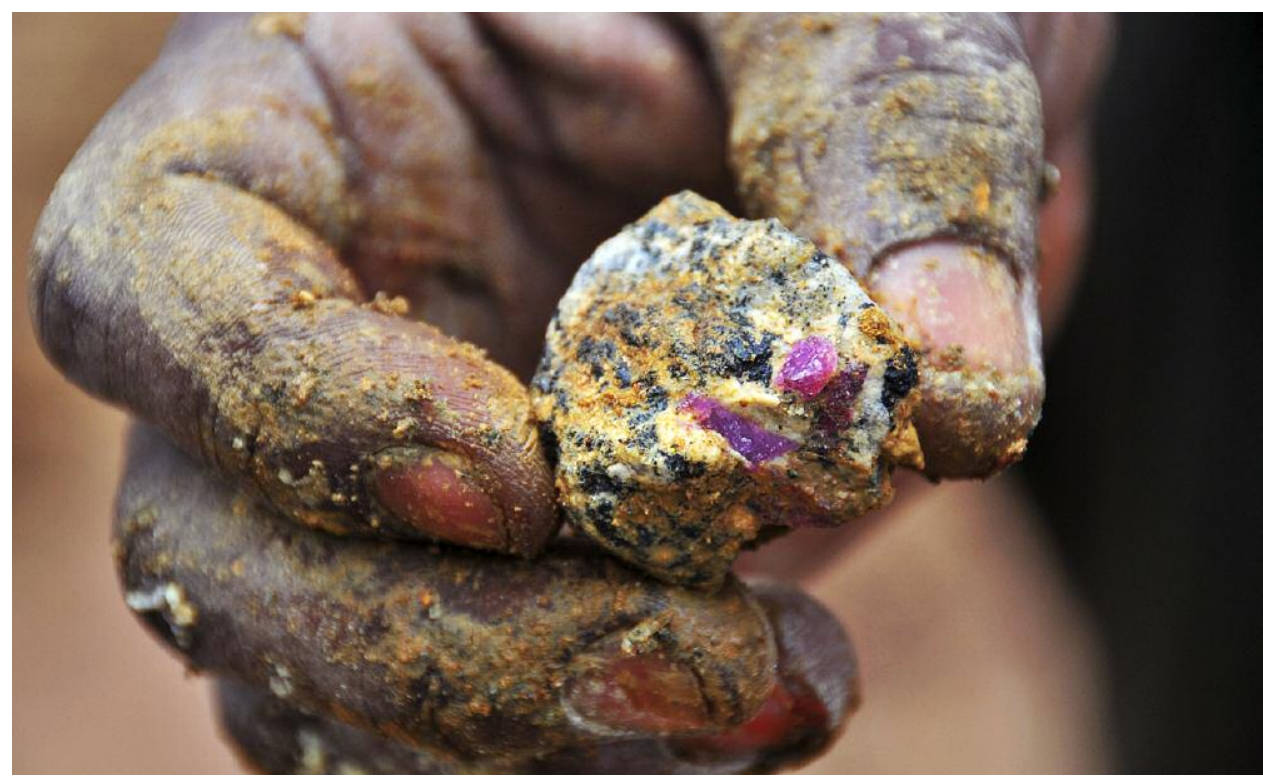

Figure 3. Ruby associated with feldspar and amphibole, found at the mining site in M'sawize, November 2009. Photo by Vincent Pardieu/GIA. 
Discovery Near Montepuez. In April 2009, rubies were discovered near the city of Montepuez in Cabo Delgado Province. This city is linked to the coastal city of Pemba by Road 242, the main transportation route in Cabo Delgado.

Unlike the other two deposits in northern Mozambique (M'sawize and Ruambeze), Montepuez is not located in a national reserve. This meant that there was potential for legal mining claims and larger-scale development. The initial production seen from the areas around Montepuez was more intensely colored and clearer than the material from Niassa, but its flatter shape resulted in lower yield after cutting.

At the time of the discovery, two deposits were known. The first was near the town of Namahaca, just north of the main road, where lower-quality material was found. The other was about $8 \mathrm{~km}$ southeast of the town of Namahumbire. This deposit yielded higher-quality ruby, with more facet-grade material available (Pardieu and Chauviré, 2012).

It is estimated that thousands of people started working this deposit in June or July 2009 without proper permits. Most of the miners were based out of the local villages. So were the "bush traders" who serve as middlemen between the miners and international buyers. These foreign buyers, located in Montepuez or Pemba, are mostly Thai, Tanzanian, and West African and have experience in the colored gemstone trade (Pardieu et al., 2013; Hsu et al., 2014).

This activity created new concerns for the government, though it was reluctant to take strong (and unpopular) measures since elections were coming up later that year. By November 2009, the artisanal mining situation had stabilized. The government had decided that artisanal, unlicensed mining would be tolerated in the area around Namahaca ("Areas Designadas"). The company that owned hunting rights on the ruby-bearing land (Mwiriti Limitada) was the first one to acquire several official mining licenses around Namahumbire (Pardieu et al., 2009a,b).

By 2010, material from the Montepuez deposit was widely available in the Asian market in all quality ranges. Fine untreated faceted stones were sold, as well as low-grade glass-filled cabochons and all qualities in between. Mwiriti officially had the mining license near Namahumbire but was unable to control and exploit the deposit at this stage. All of the production that reached the market in this period was taken out of the ground by artisanal miners known as garimpeiros, whose numbers kept grow-

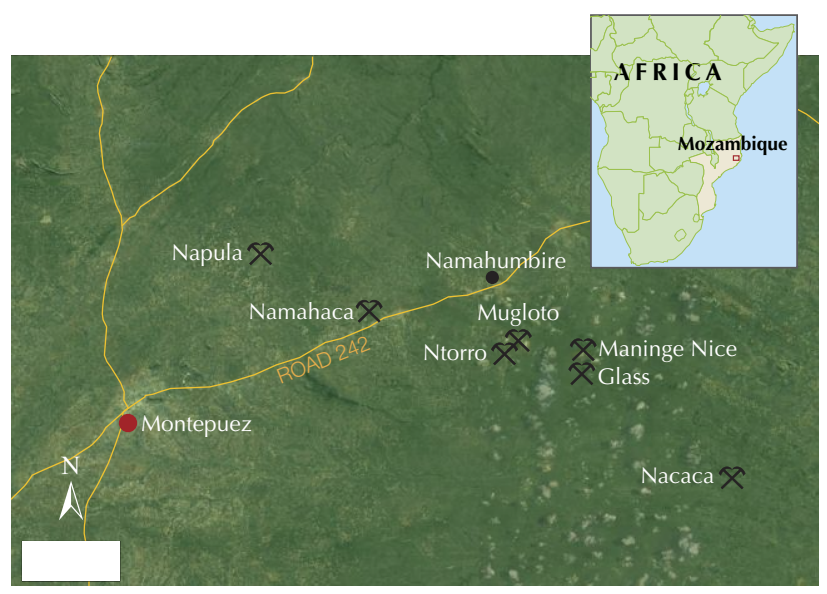

Figure 4. Map indicating the main ruby mining areas around Montepuez.

ing. It is estimated that by the end of 2010, tens of thousands of them were working the ruby deposits around Montepuez (Pardieu et al., 2013).

With the rapid influx of miners, the working area was expanded and numerous other places with ruby were discovered in the following years. The most important ruby mining areas (figure 4) during this early period were:

- Maninge Nice (discovered in 2009): This area probably relates to the original Namahumbire discovery and translates to "good quality." Nova Mina and Central were often described as separate deposits in the older literature, but they are most likely a part of what is now considered Maninge Nice. This is a primary deposit, associated with an immature secondary deposit.

- Glass (2010): This area is named after the glasslike appearance of the finest stones found here. The deposit is very close to Maninge Nice, and the rubies share many similarities, but Glass is clearly a more mature secondary deposit with rounded rough rubies.

- Nacaca (2012): This secondary deposit is about $25 \mathrm{~km}$ southeast of Namahumbire, and a variety of material is found here. This area is east and downstream of all the other deposits.

- Ntorro (2012) and Mugloto (2014): This mature secondary deposit produces a lower volume than the others, but the rubies are of much higher quality.

Maninge Nice, Glass, and Mugloto-Ntorro are all located in the concession held by Mwiriti. Most of the Nacaca deposit is outside of the concession and 
has been allocated to artisanal miners as Areas Designadas, similar to the area around Namahaca.

In June 2011, Mwiriti (25\%) signed a joint venture agreement with Gemfields $(75 \%)$, and Montepuez Ruby Mining (MRM) was formed to exploit the deposits near Namahumbire. After a year of mine development, MRM took its first rubies out of the ground in late 2012 (Lucas and Pardieu, 2014). The establishment of MRM drastically changed the dynamics of the Montepuez deposit. Unlicensed miners were restricted to certain areas while MRM developed the concession at an industrial scale. The large-scale development of MRM attracted other investors, and in 2016 several other mining groups started showing interest in the ruby deposits around Montepuez. The second company to commercially produce rubies was Mustang Resources, which worked on ruby mining concessions west and northwest of Namahumbire around the village of Napula (Lucas and Hsu, 2017; Pardieu, 2017). In late 2017, the newly formed Fura Gems acquired several exploration licenses north of Namahumbire. In mid2018, Mustang Resources and Fura Gems merged their ruby assets, which are now handled by Fura.

Although the lion's share of ruby-bearing land is officially under control of large groups that obtained the legal mining/exploitation rights, unlicensed artisanal miners are still prevalent. The areas are simply too large to secure entirely. This has led to conflicts between private security forces, police forces, and artisanal miners (Hsu et al., 2014). Journalists have made claims of human rights abuses, both by police forces and private security firms, since 2015, most notably in a television documentary produced by $\mathrm{Al}$ Jazeera (Valoi and Macrae, 2015). In January 2019, Gemfields paid US\$7.8 million to settle human rights abuses brought against it by the local community (Gemfields, 2019).

Over the years, a delicate balance was struck between the unlicensed miners and the license owners with regard to the ruby-bearing grounds. Although the mining rights belong to the license holder, unlicensed miners are often tolerated on parts of the concession. For example, Ntorro and Glass were worked by garimpeiros for years before the license owner started developing large-scale mining operations at these deposits.

At the time of this writing, there are two major players in the Montepuez ruby mining area: MRM and the artisanal mining community. The artisanal mining community around Montepuez has faced many challenges since the rubies were first discovered. For a while, they were able to work in the Areas Designadas around Namahaca and Nacaca, but these areas were later incorporated into larger mining licenses. Mining without a license was also not considered a major criminal offense until February 2016, which meant that garimpeiros who were caught could not be prosecuted. Mining without a license is now punishable by law, and the miners face considerable jail time and fines if caught (Vertriest and Pardieu, 2016). These factors, combined with the more established security of larger companies, have caused the supply from garimpeiros to drop considerably. In the early days (pre-2014), they accounted for nearly 100\% of Mozambican ruby production; now it is far less.

It is important to note that only companies with a mining license are allowed to export gemstones out of Mozambique. This means that all rubies on the market that were mined by unlicensed miners left the country illegally.

\section{MOZAMBIQUE RUBIES IN THE MARKET}

Mozambican Ruby Trading. The first material from the Niassa deposits came to the international market through Tanzania. Before the discovery of Mozambican ruby, many buyers on the African mainland were based in Tanzania and Kenya. These international merchants had cash available and were knowledgeable about exporting procedures, so they were the first to see new goods. Since the initial material from Niassa was not of the highest grade, few merchants felt the need to pay attention to Mozambique. However, when the supply from Winza, Tanzania, began to decline, buyers started looking for other sources of ruby (Pardieu et al., 2009a,b).

By late 2009, the Montepuez deposit was starting to reveal its potential, and many merchants moved to Mozambique to establish a presence in Pemba or Montepuez. While the color of the material was very desirable, it often required treatment such as glass filling or heating with flux to address the abundant fractures. The Thai trading centers have a wealth of experience in enhancing ruby, with regard to both color (heat treatment is often required to optimize Thai and Cambodian ruby) and clarity (heating with flux to heal fractures, often done on Mong Hsu rubies, and glass filling, perfected on low-grade rubies from Madagascar). So nearly all production went to Thailand to be treated, cut, and sold in the trading centers of Bangkok and Chanthaburi. By the end of 2009, Mozambican ruby was flooding the Thai market.

In 2012, an important discovery was made in the Montepuez mining area, when rubies with a different 
appearance were found. This was in an area called Ntorro. These stones had a more orangy bodycolor than the early Montepuez production, with subtle bluish color zones, bulky shapes, and a cleaner appearance overall. Furthermore, these rubies did not have abundant fractures and did not require clarity enhancement by heating with flux or glass filling. They do benefit from heat treatment to optimize the color, an area in which the Sri Lankans have great experience. Since the discovery of this type of material, Sri Lankan traders have also started buying material in the local market.

Mugloto-Ntorro produces a much lower volume than the others, but the value is much higher. This area has produced many important stones, including some of the most famous Mozambican rubies sold to date: the Dragon Eye rubies, the Rhino ruby, and the Rose of Mozambique.

In June 2014, Gemfields hosted the first auction of rough ruby from its mine near Montepuez (Lucas and Pardieu, 2014). This event, held in Singapore, represented the first legitimate public sale of Mozambican ruby since its discovery. The sale presented material from the Mugloto and Maninge Nice areas within MRM's concession. Some of the material was disclosed as treated, but the majority was guaranteed to be untreated. At the inaugural auction, 2.03 million carats were offered, of which 1.82 million carats were sold.

The material at these auctions is put in pregraded lots, where goods of similar quality and color are offered together (Shor and Weldon, 2015). The impact of Mozambican ruby became very clear when a well-known dealer said, "Before the Mozambique discovery, it would take several years to collect a full suite of color-matched rubies of equivalent quality. Now I can buy a full suite, and in six months a new one will be auctioned."

So far Gemfields has organized 12 ruby auctions, which have generated over US\$500 million in revenue for nearly 10 million carats of rough ruby.

In October 2017, Mustang Resources held an auction in Mauritius that offered 22 lots of ruby and pink sapphire. Only eight of the lots were sold, generating US $\$ 550,000$ (Pardieu, 2018). After the auction, they started selling the material through a sales office in Thailand ("Mustang Resources realizes maiden ruby sales...," 2018).

Apart from these auctions and some private sales by the mining companies, most of Mozambique's rubies have reached the market through unlicensed channels.
Presence in the Market. For centuries, the world's ruby supply was dominated by two sources: modern-day Sri Lanka and Myanmar (specifically Mogok). From the late 1800s until the 1990s, the border area of what is now Thailand and Cambodia also produced high-quality gems, although this deposit only became dominant in the 1960s, when the Burmese regime closed itself, and its ruby resources, from the rest of the world. Other historical sources such as Afghanistan have never produced comparable volumes or qualities.

Only in the last decades have other competitive sources appeared. These often showed great potential but lacked the volume (e.g., Winza, Morogoro, Vatomandry, or Luc Yen) or the facet-grade quality (e.g., Mangare) to cause a major shift in the global ruby trade. The most important new deposit in this period was Mong Hsu, Myanmar. This was the major source for rubies in terms of volume since its discovery in the early 1990s until the emergence of the Montepuez deposit (Hughes et al., 2017).

The Montepuez deposit has made ruby more accessible than ever before. Mozambique has joined an elite club of ruby producers and impacted the gemstone trade in ways never imagined before (Hughes, 2015). Mozambique offers everything from huge unheated stones with top color to sub-millimeter pinkish treated melee. This has increased the availability of ruby in all quality ranges and sizes.

We have to remember that gemstones are not perishable goods, and almost every stone that has entered the trade is still out there. A deposit such as Mogok has more than a thousand years' head start, yet nowadays the booths in major tradeshows offer the same volume of Burmese and Mozambican gems. The balance even shifts toward Mozambique.

\section{GEOLOGY}

The geology of northern Mozambique is very complex and not well understood. The area is sparsely inhabited, and very few geologic surveys have ever been carried out.

The large-scale geology is dominated by features related to the East African orogeny. The most important structure is the Mozambique Belt, a suture zone that developed during the formation of the Gondwana supercontinent. Currently it stretches from central Mozambique up into the Arabian Peninsula. Most of the islands in the Indian Ocean (including Madagascar and Sri Lanka) as well as parts of southern India and eastern Antarctica also belong to the Mozambique Belt. Though now exposed at the surface, it was once covered by more than $10 \mathrm{~km}$ of 
rocks, which caused it to reach high temperatures and subjected it to large pressures (Lächelt, 2004; Grantham et al., 2008; Bingen et al., 2009).

The primary ruby deposits are hosted in the Montepuez complex. This wedge-shaped group of rocks deformed at high metamorphic conditions. Its main rock types are orthogneisses with various compositions (granitic to amphibolitic) and paragneisses including quartzite, meta-arkose, marble, and biotite gneiss. The age of these rocks is Meso- to Neoproterozoic (1.6-1.1 Ga). Numerous younger intrusions of granite, granodiorite, and tonalite can be found throughout the complex (Boyd et al., 2010).

During different orogenic phases, the Montepuez complex has been subjected to intense tectonism, resulting in a very complex structural framework. The rock units are tightly folded and cut by several shear zones that mainly trend northeast to southwest. This took place during the Mozambican orogeny (1100$850 \mathrm{Ma}$ ) and the East African orogeny (800-650 Ma). Another tectonic event altered these rocks around $538 \mathrm{Ma}$, when thrust faults, folds, and shear zones developed as a part of Pan-African mountain-building processes (Lächelt, 2004).

The geology on a more local scale is not well known, since outcrops are very scarce. Most of the bedrock is covered by up to 20 meters of soil. Due to the climate in northern Mozambique, rocks weather very quickly, and thus the top layers of the bedrock are intensely altered. This makes it very challenging to study the geology in outcrops or even in shallow drill holes.
Based on observations during field visits, the ruby mineralization is closely related to rocks rich in amphibole, mica, and feldspar. This is the reason we classify the Montepuez ruby find as an amphibolerelated deposit (Hsu et al., 2014). Other studies mention the presence of kyanite and siderite associated with the amphibole-rich host rock of the rubies (Hänni and Krzemnicki, 2009).

\section{DEPOSITS}

Rubies are found in two types of environments around Montepuez: primary and secondary. The secondary deposits consist of more concentrated layers of gravel in which the host rock has been broken down and the more resistant material has been concentrated. There are several ways this could have happened: (1) the host rock weathered and the remaining stones were not transported (eluvial deposit); (2) the stones were transported by mass movement (colluvial); or (3) the stones were transported by water (alluvial). The earliest interpretations stated that the large secondary deposits in Mugloto-Ntorro were alluvial and caused by some sort of flash flood that was later reworked by river systems (Chapin et al., 2014; Hsu et al., 2014). However, field observations by the author and by one of the leading authorities on geological exploration in East Africa (Simonet, 2018) do not match this theory. In an alluvial system, rounded pebbles, well-sorted sediments, and various grain sizes would be found. The secondary deposits near Montepuez are unsorted and form one continuous layer of gravel that has sharp boundaries (figure 5). According to Simonet,

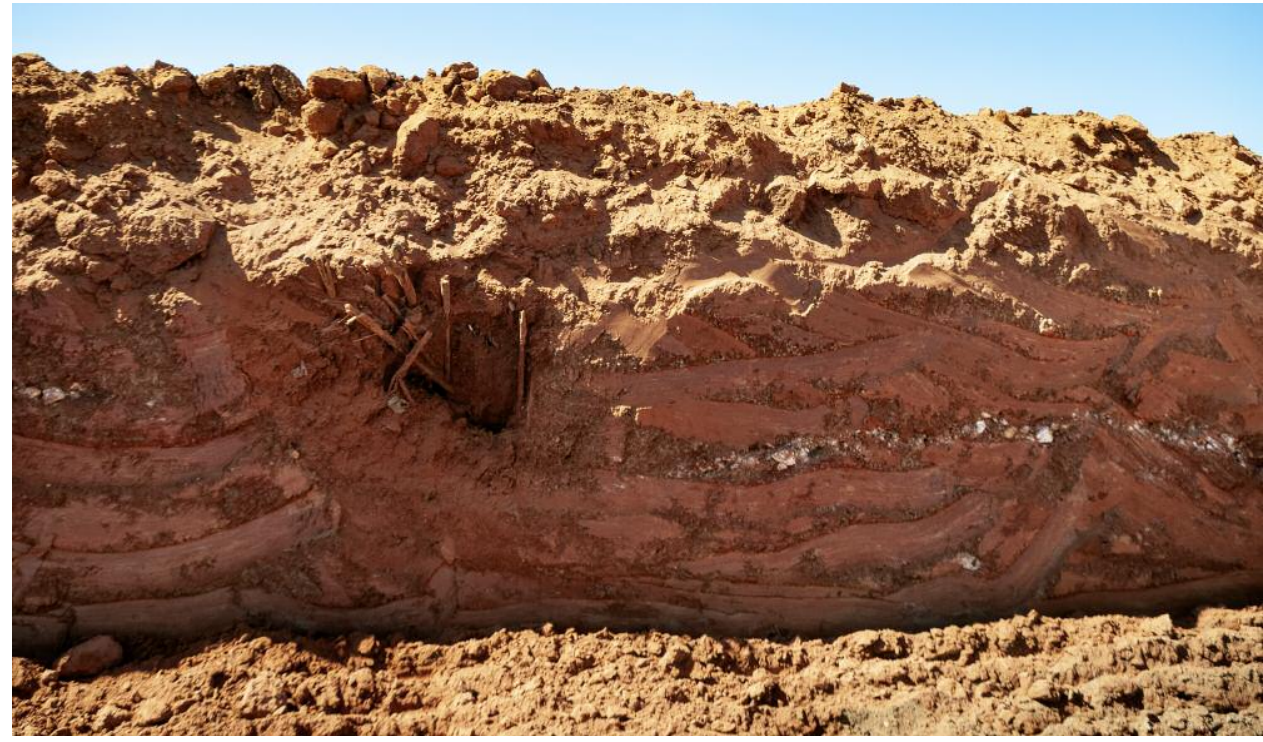

Figure 5. At the Mugloto pit, operated by MRM, a gravel layer containing rubies and quartz boulders in the secondary deposits is clearly visible. A tunnel that was supported by wooden structures is an indication that artisanal miners used to work in this area. Photo by Wim Vertriest. 
this is consistent with the "weathering down" of rock masses. During this process, the rocks weather and erosion products get carried away. The most resistant material (garnet, corundum, and quartz boulders) is left behind and ultimately concentrated in one layer. This material has not been significantly transported by rivers or any other means.

Smaller-scale alluvial deposits are also present around Montepuez, where rivers and creeks have carried material of the different ruby-hosting rocks and dropped them in recent river sediments.

Primary deposits are those in which ruby is still found in its original host rock. In the case of the Mozambican ruby deposits, the original host rock is so strongly weathered as to be nearly unrecognizable. Most of the minerals are turned to clays and other alteration products. People working in the mine describe the host rock as "rotten" (figure 6). The primary deposit of Maninge Nice is overlain by a secondary deposit derived from it. This highergrade deposit was probably the first discovered in Montepuez.

Because the primary deposits are so weathered, they are in a way easier to mine than the secondary deposits. This is counterintuitive, since we associate primary deposits with hard rock mining, tunnels, and blasting. However, the rock has been turned to clay, which is considerably easier to mine when it is dry. Pieces of dried clay can be crumbled between your fingers, turning everything except the rubies to dust. This makes excavation with excavators very simple, as opposed to the secondary deposits where large

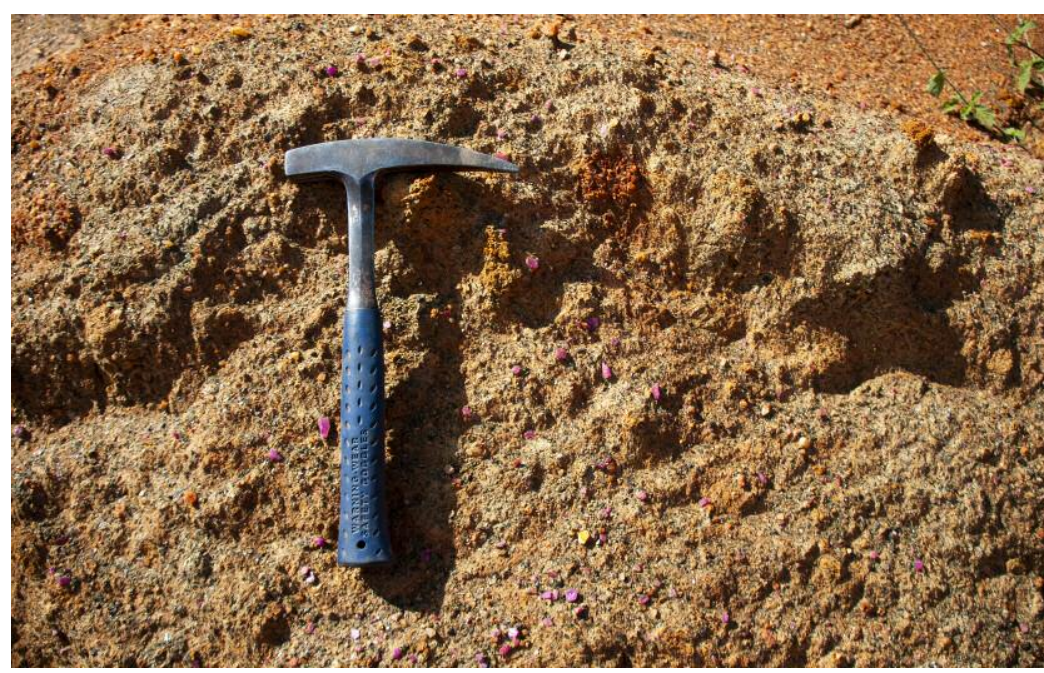

Figure 6. The primary deposit in Maninge Nice contains extremely weathered amphibole-rich rock in which rubies are literally falling out of their host rock. Photo by Wim Vertriest.

quartz boulders make excavation more difficult. The situation reverses during the intense rainy seasons, with the clay turning into a sticky mass. Even the heaviest equipment cannot combat such conditions, and thus mining of the primary deposit only takes place for half of the year.

\section{MINING}

Artisanal miners usually work with very simple tools. Using shovels and picks, they dig into the earth to reach the gravel layers in the large secondary deposits (figure 7). Sometimes they support their shafts

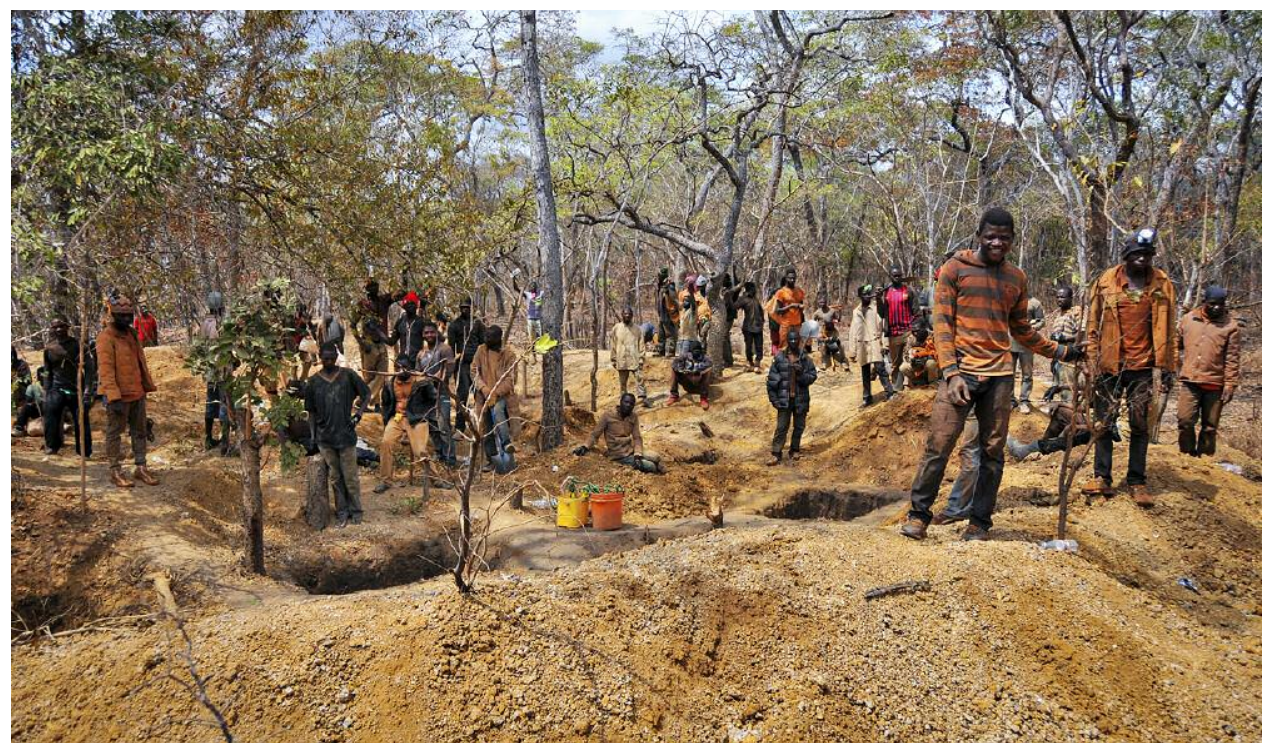

Figure 7. A group of garimpeiros at their workings in the bush near Montepuez. Photo by Vincent Pardieu/ GIA, September 2014. 


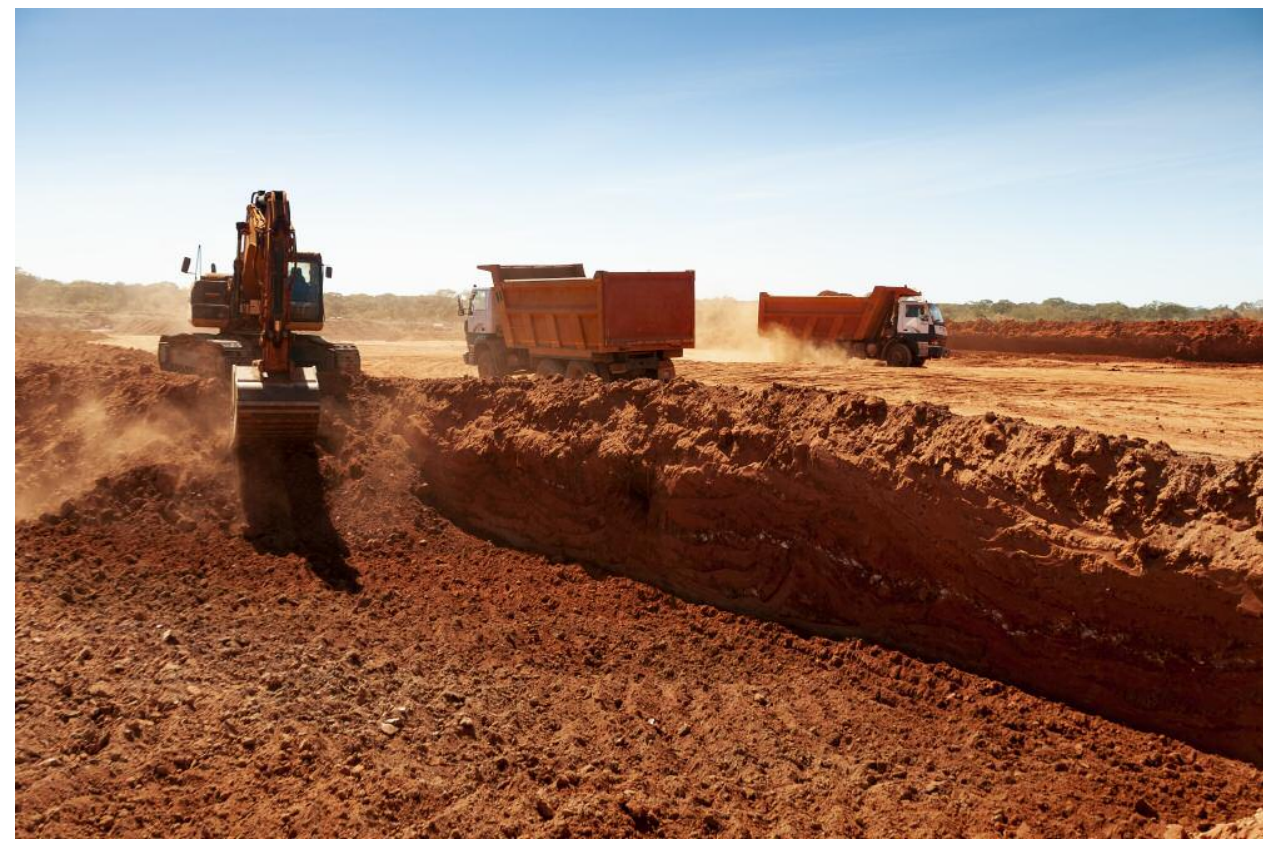

Figure 8. Large-scale mining in the Mugloto area. Photo by Wim Vertriest, July 2016.

and short tunnels with wooden structures, but in most cases they do not. Ruby-bearing gravel is taken from these pits and transported to a washing place. Using simple instruments such as washing pans or crude grids, they screen the material for rubies. In the early years of the deposits' development, several accidents happened due to poor mining conditions in artisanal workings. In the last three to four years, the number of garimpeiros has decreased and there have been fewer reports of accidents.

A similar process is followed at other alluvial deposits where rubies are found in recent gravels, often reaching the surface. This requires less work since no pit needs to be dug, but the ruby concentration is often a bit lower. These mining sites tend to be much smaller and localized, diminishing the chances of finding high-quality ruby.

The large-scale operations by major companies use industrial setups with excavators and dump trucks to move overburden and ruby-rich gravel. They build up a stockpile, mining material they can process later. This is because the rainy season makes it very difficult to extract the gravel for about half the year. The washing operations run year-round, using different techniques (figure 8).

Gemfields has opted for a series of screens and gravitational jigs to sort and concentrate the ruby. Mustang worked with rotary pans, where minerals are also concentrated based on their density. In 2017, Gemfields added dense media separation (DMS) techniques to pre-concentrate the gravels and optimize the efficiency of their jigs (Pardieu, 2017).
These techniques all require large amounts of water, so serious investments have been made to guarantee clean water supply, either in the form of artificial lakes, water treatment plants, or a combination of both.

The large companies also have extensive exploration programs that use a combination of core drilling, auger drilling, and geophysical analysis to determine the extent of ruby-bearing areas (Hsu et al., 2014).

\section{GEMOLOGICAL ANALYSIS}

Standard Gemological Properties and Appearance. Mozambican rubies generally have purplish red to red colors; some stones have an orange tint. Color intensities cover the spectrum from pale pink sapphires to deep red rubies. Standard gemological properties are consistent with gem corundum: a refractive index between 1.760 and $1.768(+/-0.001)$, a birefringence of $0.008-0.009$, and a specific gravity average of 3.98-4.00. Fluorescence can be strong to medium red under long-wave UV radiation and medium to weak red under short-wave UV.

Based on their appearance, we can classify Mozambique's rubies in two major types. These types are named after the locality where they are most dominant, but they are by no means exclusive to these areas. Some Mozambican rubies share characteristics of both types, but these are considered rare.

The first type is named after Maninge Nice (figure 9). This material represents the first rubies mined around Montepuez in 2009. They show a strong flu- 


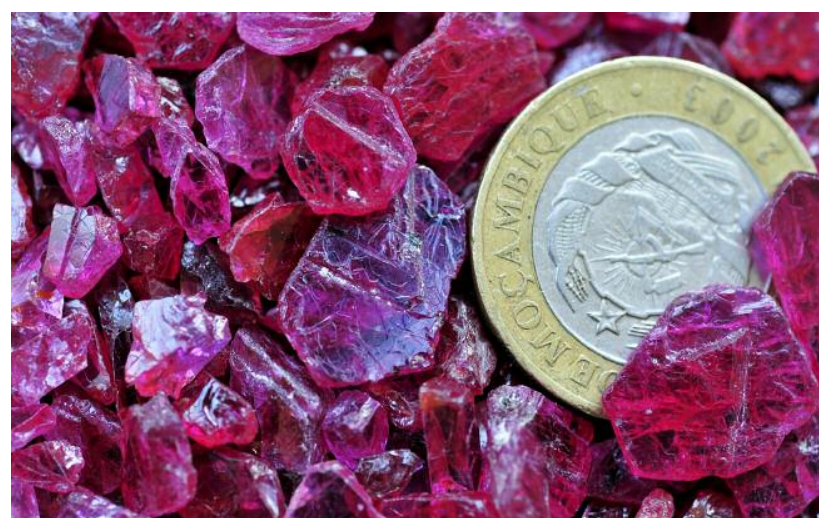

Figure 9. Typical Maninge Nice-type rubies with a deep red color and strong UV reaction. Their flat hexagonal shape is typical of stones from a primary deposit. The coin shown as a reference has a diameter of $25 \mathrm{~mm}$. Photo by Vincent Pardieu/GIA.

orescence reaction to long-wave UV exposure and have a variable color intensity ranging from pink to deep red. They tend to be associated with primary deposits. This means that the flat hexagonal crystal shape is often preserved.

The second type is called Mugloto (figure 10) and has been mined since 2012. The first Mugloto-type material was mined in Ntorro by artisanal miners, but since its discovery and large-scale exploitation in 2014, the nearby Mugloto area has been the main source for this type of material. Its fluorescence reaction to UV exposure is weaker, and its bodycolor appears to have a subtle orangy tint. Some Muglototype stones have bluish color zones. The material often has a bulkier shape since it is only found in weathered deposits.

Figure 11. Bands of silk, often visible in a hexagonal configuration at $120^{\circ}$ angles, are a common inclusion in Mozambican rubies. Photo by C. Khowpong; field of view $2.50 \mathrm{~mm}$. Fiber-optic illumination.

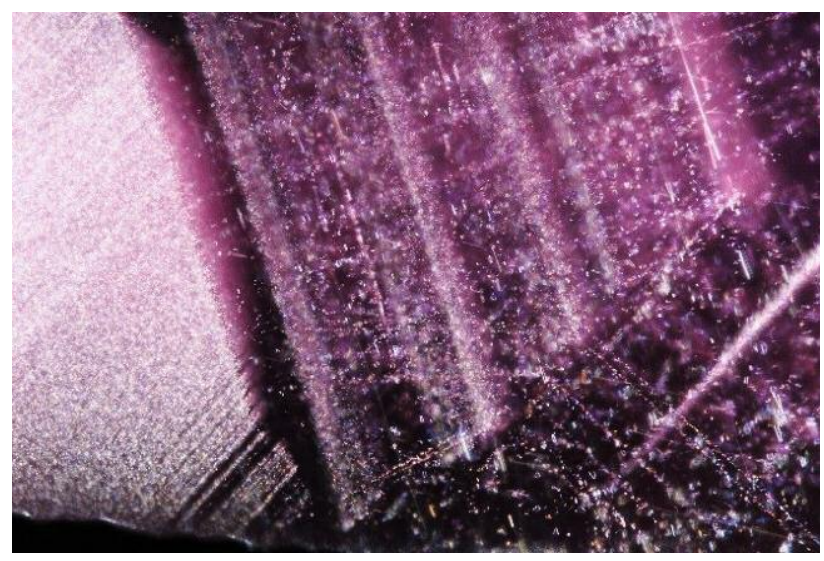

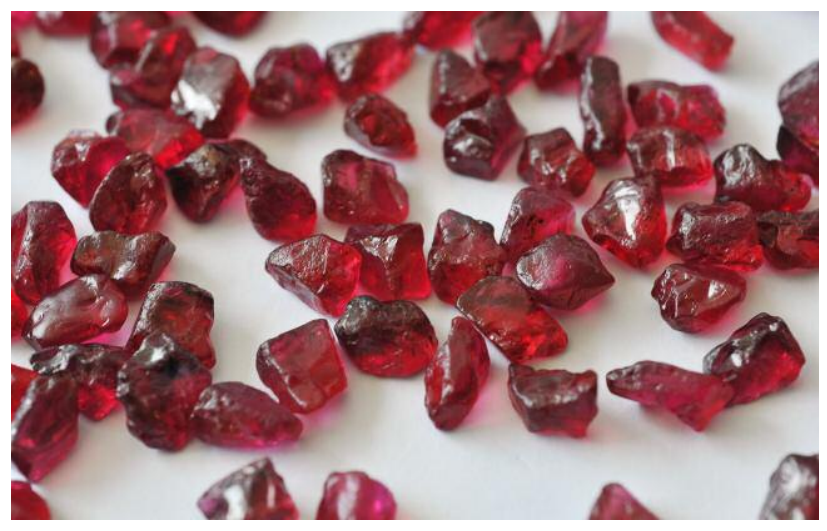

Figure 10. Typical Mugloto-type rubies with a nice red color. The blocky shapes are typical of a secondary deposit. These stones weigh around 1 gram each. Photo by Vincent Pardieu/GIA.

Microscopic Observations. The most common inclusions are particles (McClure and Koivula, 2009; Pardieu et al., 2009a,b; Hänni and Krzemnicki, 2009; Pardieu et al., 2013, 2015; Saeseaw et al., 2018). In many cases, these oriented needles and particles appear in bands following the corundum growth structure (figure 11). These full hexagonal outlines are commonly seen in Maninge Nice-type rubies. Mugloto-type rubies seldom show the full hexagonal outline but often have straight or angular bands of particles.

Particles can have various shapes, but irregular and arrowhead forms are often seen. Finer particles and platelets can be challenging to observe without fiber-optic illumination under the correct angle (figures 12-14). Some of the needles and smaller particles are similar to rutile particles frequently found in

Figure 12. Reflective particles and platelets are very common but take some practice to observe with a fiber-optic light. Photo by B. Kongsomart; field of view $1.35 \mathrm{~mm}$. Fiber-optic illumination.

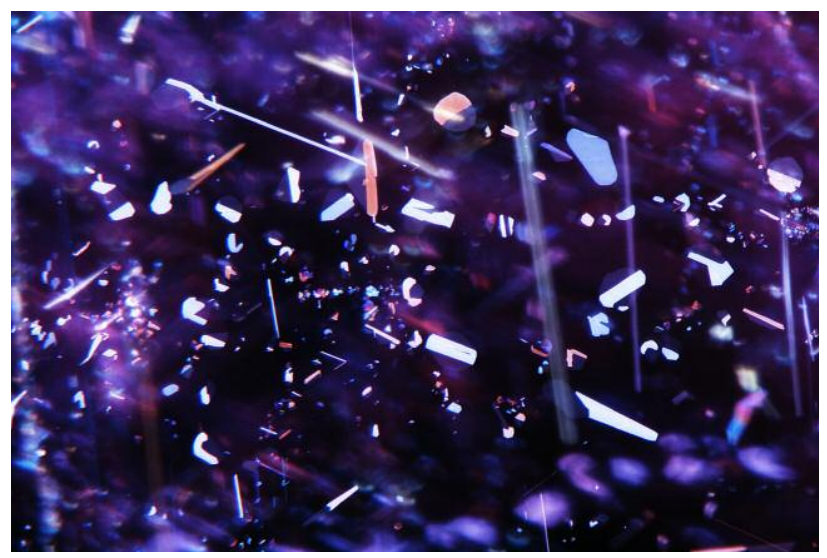




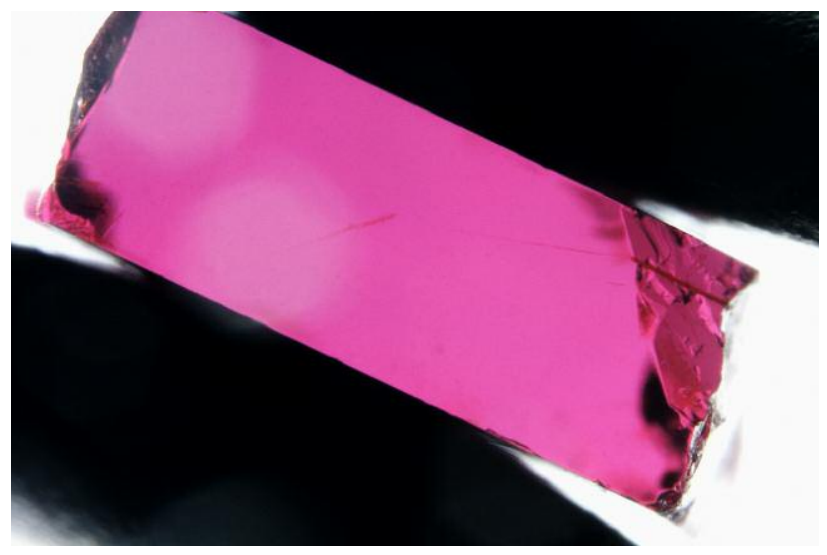

Figure 13. A Mozambican ruby appears clean when viewed in brightfield illumination. Photo by GIA; field of view $12.3 \mathrm{~mm}$.

other rubies, but the nature of the finer platelets is still unclear. Tubes, associated with twin planes, are also frequently observed (figure 15) (GIT Gem Testing Laboratory, 2009; Pardieu et al., 2013).

A variety of mineral inclusions are observed in Mozambican rubies. Rounded greenish amphibole crystals are often found in sub-spherical shapes (figure 16) but can be seen as elongated rods (figure 17). Pseudohexagonal mica platelets (figures 18 and 19) appear frosty and are often associated with fringes, indicating an alteration of the mica during the geological history of the ruby. Around these crystals, a planar feature of flat fluid "rosette" inclusions is

Figure 15. Intersecting tubes associated with twin planes are frequently seen in Mozambican rubies. Photo by Jonathan Muyal; field of view $2.65 \mathrm{~mm}$. Darkfield illumination.

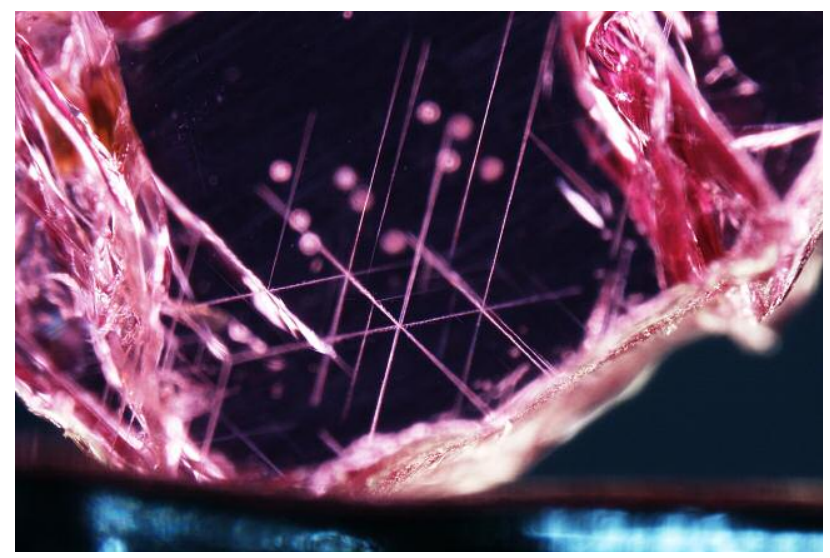

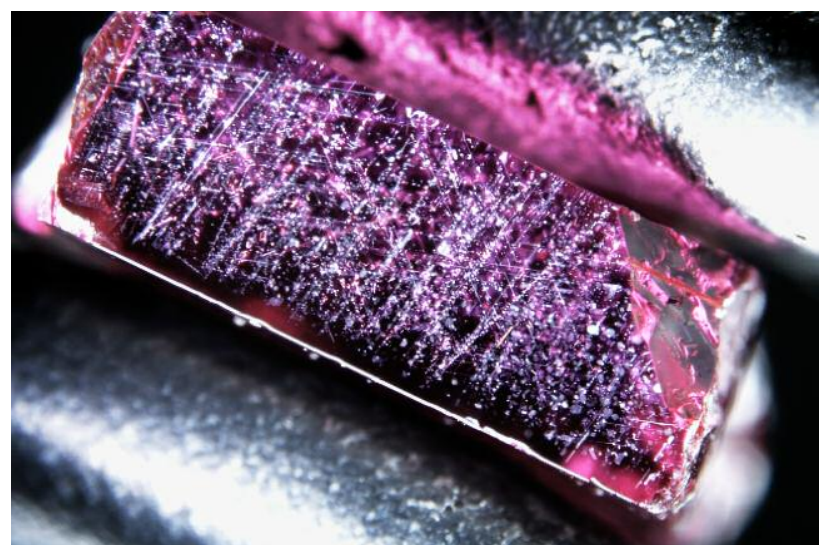

Figure 14. The ruby from figure 13 shows a variety of particles and platelets when a fiber-optic light is shined through it at the correct angle. Photo by GIA; field of view $12.3 \mathrm{~mm}$.

often seen. Opaque cubic crystals are common in rough crystals but not in faceted stones because they contrast very strongly with the reddish background color of the rubies (figure 20). On top of that, these black inclusions react very poorly to heat treatment, even at lower temperatures. These crystals have been identified as chalcopyrite (Pardieu et al., 2013).

Both types of Mozambican ruby have the same inclusions, but their abundance varies. We noticed that Mugloto rubies somehow contained fewer mineral crystals than rubies from Maninge Nice. Maninge

Figure 16. These two greenish amphibole crystals, identified by Raman spectroscopy, represent the most common crystal inclusion in Mozambican ruby. The smallest shows the typical rounded, elongated shape, while the larger crystal has a more irregular shape. Photo by C. Khowpong; field of view $1.42 \mathrm{~mm}$. Brightfield illumination.

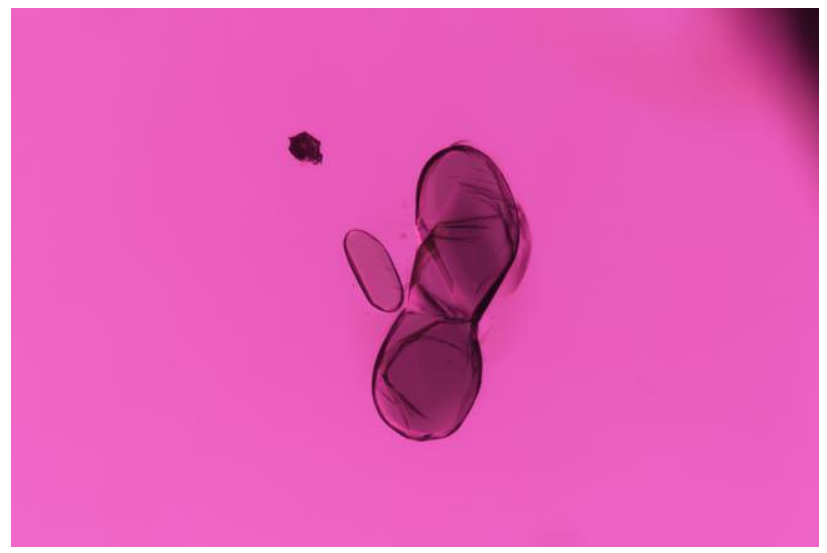




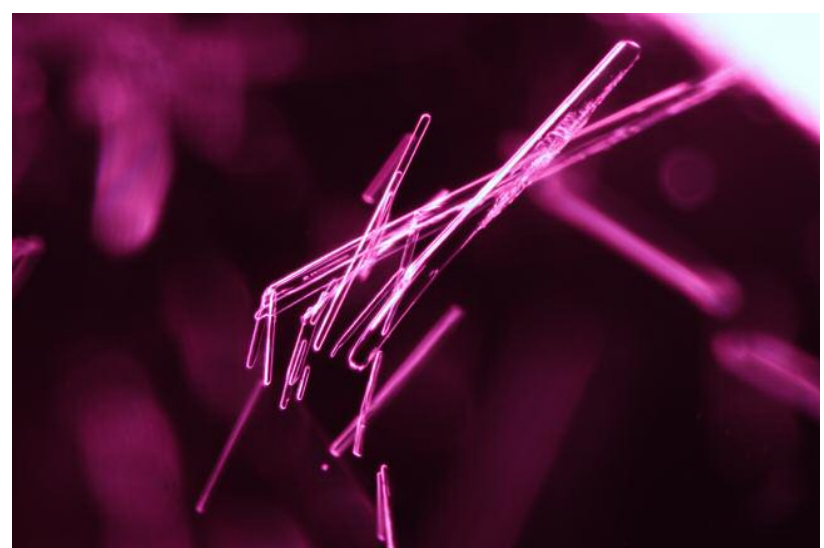

Figure 17. In some cases, amphibole occurs as elongated rod-like crystals. Photo by C. Khowpong; field of view $1.41 \mathrm{~mm}$. Darkfield illumination.

Nice rubies also have more fractures, which can be explained by their occurrence in a primary or nearprimary deposit.

FTIR and UV-Vis-NIR spectroscopic analyses and LA-ICP-MS chemical analyses were done at GIA laboratories following GIA's internal procedures. These methodologies are outlined in full detail in Saeseaw et al. (2018).

Infrared Spectroscopy. Infrared spectroscopy analyzes the absorption in the infrared spectrum by a gem. Most instruments measure a range from 7500 to 370 $\mathrm{cm}^{-1}$, but most useful is the functional group from 4000 to $1000 \mathrm{~cm}^{-1}$.

Figure 19. A cluster of crystals following the hexagonal growth pattern of corundum is observed at the core of this ruby. Photo by C. Khowpong; field of view $2.85 \mathrm{~mm}$. Darkfield illumination.

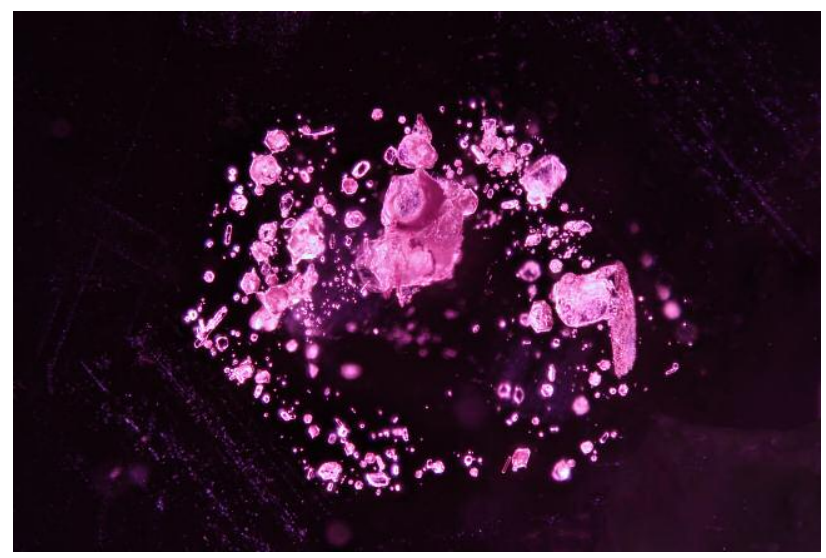

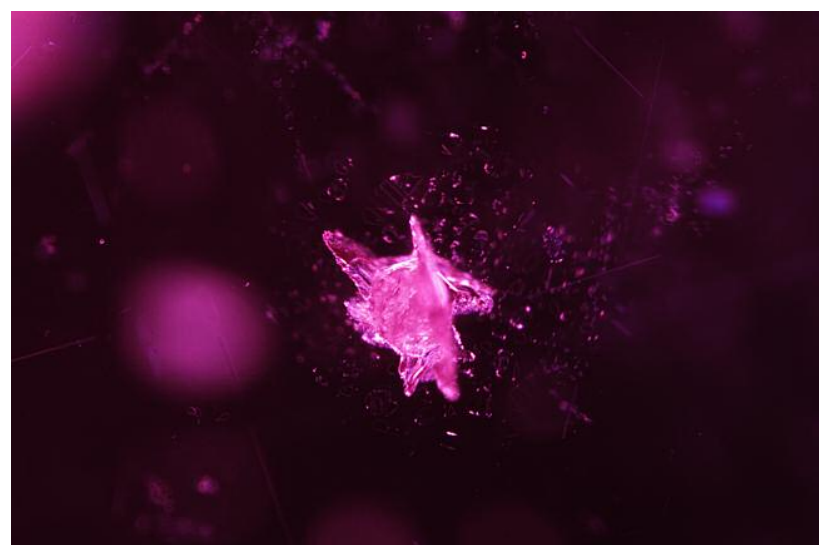

Figure 18. Pseudohexagonal mica with fringes (small expansion fractures) and a rosette pattern are a common sight in Mozambican rubies. Photo by C. Khowpong; field of view $1.12 \mathrm{~mm}$. Darkfield illumination.

This technique is best known from emerald analysis, where Fourier-transform infrared (FTIR) spectroscopy is used to identify fracture-filling material. In corundum, it can provide indications of heat treatment (Smith, 1995; Hughes et al., 2017). Very often FTIR spectra of untreated rubies show the presence of other mineral contaminants lining fractures or twin planes. Other peaks in the spectrum are commonly related to the presence of $\mathrm{OH}$ groups in the corundum lattice (Beran and Rossman, 2006).

Figure 20. Opaque black-red crystals, presumably chalcopyrite, are common in rough rubies from Montepuez. They are rarer in finished stones because of their high contrast with the host material. Photo by C. Khowpong; field of view $1.00 \mathrm{~mm}$. Fiber-optic illumination.

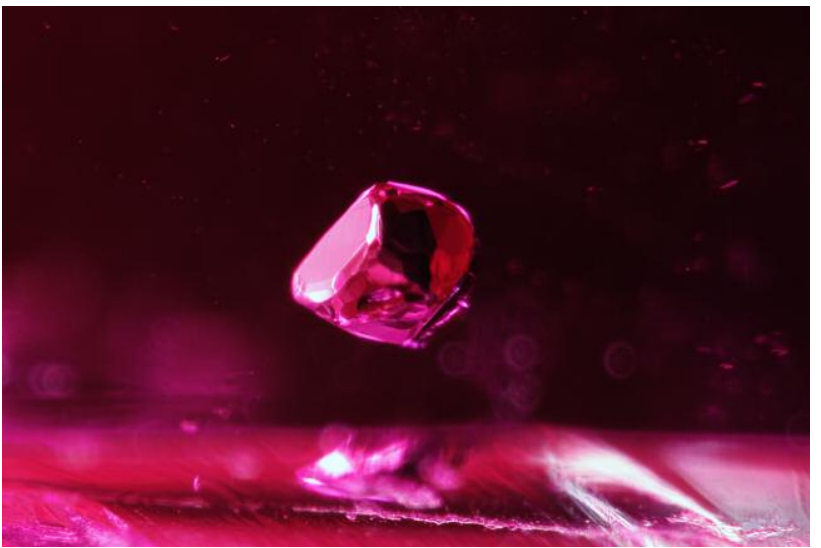


TABLE 1. FTIR spectrum types most commonly encountered in Mozambican rubies.

\begin{tabular}{lcccccc}
\hline Number of samples & Spectrum A & Spectrum B & Spectrum C & Spectrum D & Other minerals & Total \\
\hline Mugloto-type & 97 & 17 & 42 & 17 & 2 & 175 \\
Maninge Nice-type & 55 & 9 & 19 & 6 & 16 & 105 \\
\hline
\end{tabular}

Most FTIR spectra from Mozambican rubies can be grouped in one of four categories (table 1 and figure 21):

- Spectrum A is characterized by a single peak at $3309 \mathrm{~cm}^{-1}$.

- Spectrum B shows the presence of boehmite, an aluminum oxide hydroxide, through a group of distinct bands in the $3600-2500 \mathrm{~cm}^{-1}$ region.
- Spectrum C shows the presence of the clay mineral kaolinite, characterized by absorption peaks at $\sim 3695,3650$, and $3620 \mathrm{~cm}^{-1}$.

- Spectrum D has a peak at $23161 \mathrm{~cm}^{-1}$, accompanied by peaks at 3240 and $2420 \mathrm{~cm}^{-1}$.

In some cases, these four patterns are obscured by peaks related to other mineral inclusion species. These are more common in Maninge Nice-type rubies.

Figure 21. Four different FTIR spectrum types seen in Mozambique rubies.

\section{FTIR SPECTRA}
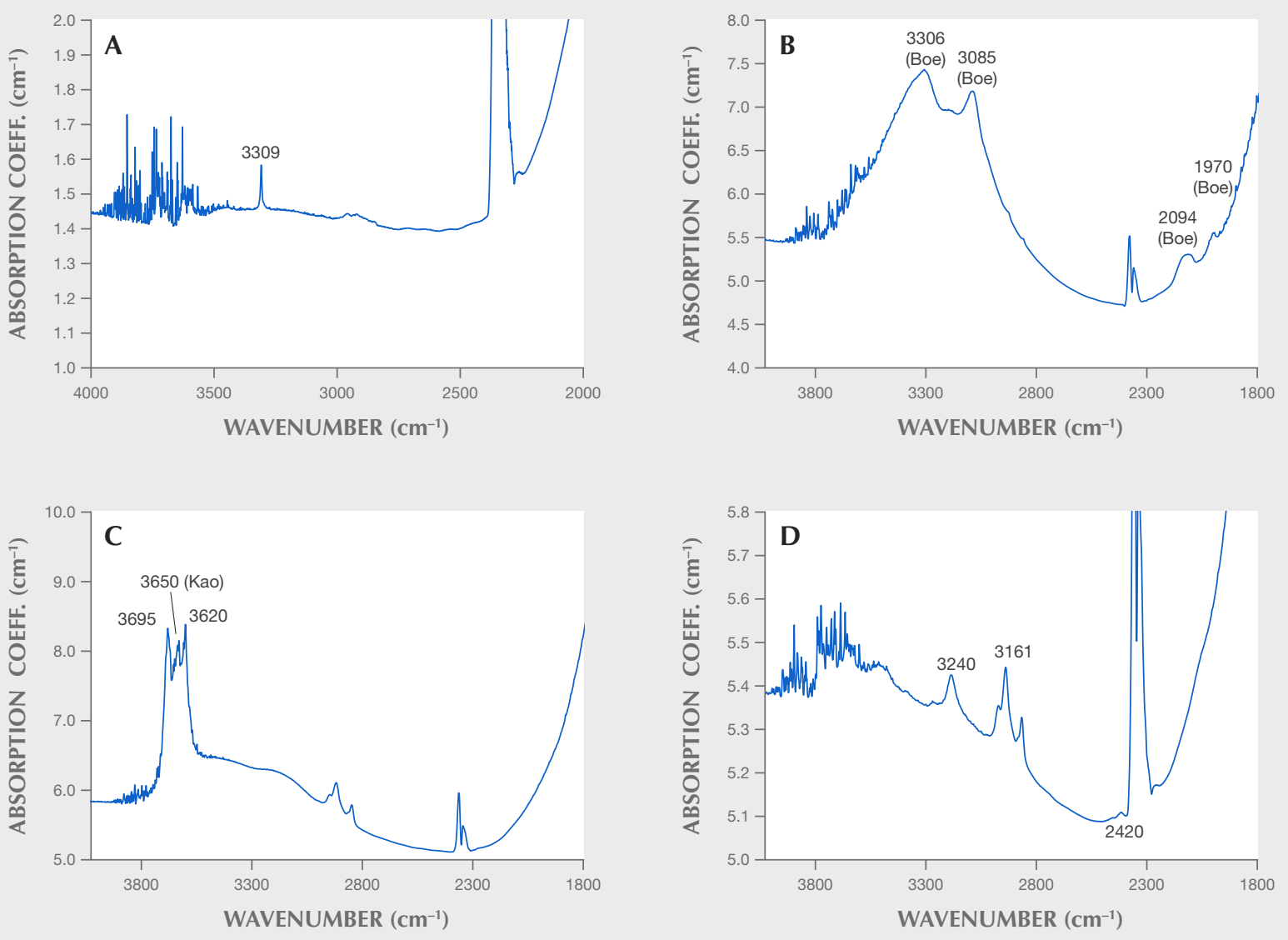


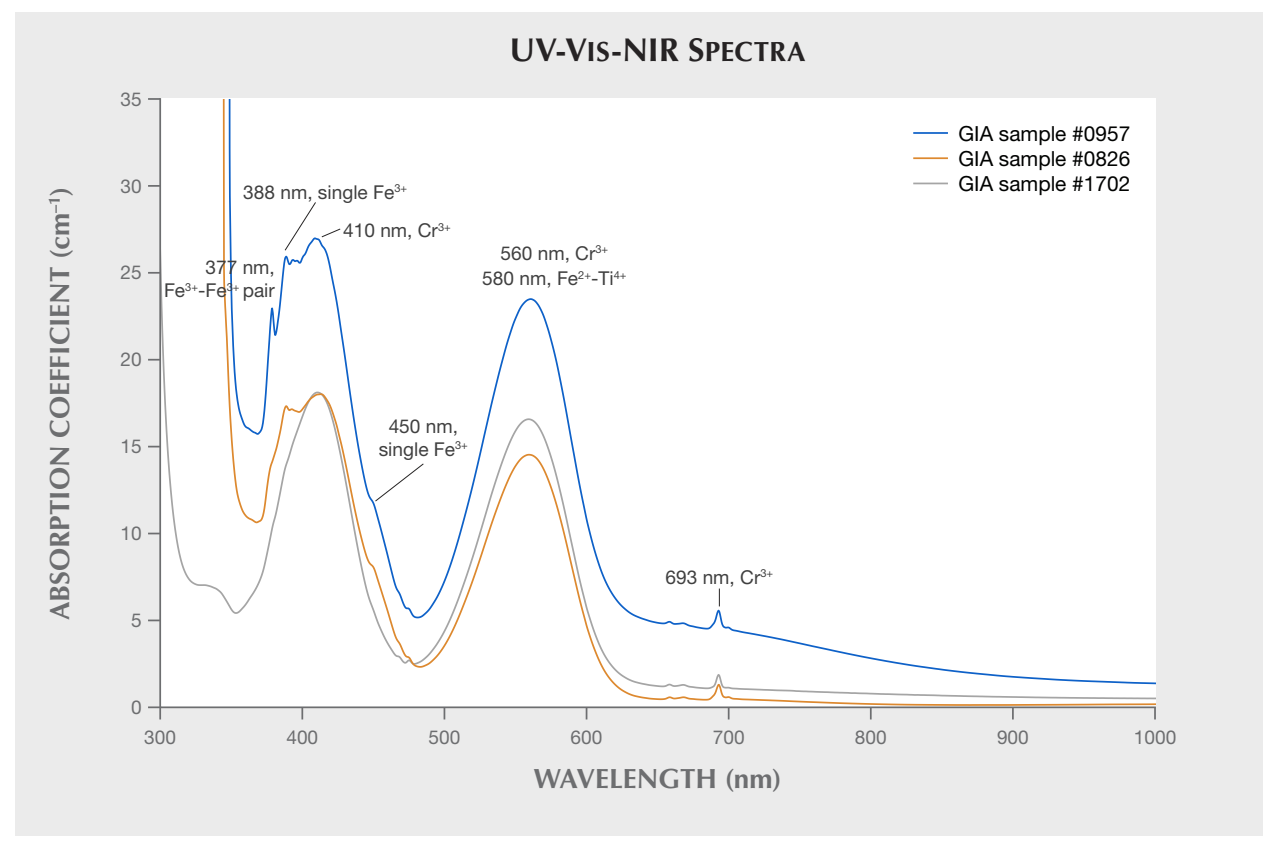

Figure 22. Comparison of ordinary UV-VisNIR spectra from GIA samples 1702 (1.163 $\mathrm{mm}$, Maninge Nicetype), $0826(2.808 \mathrm{~mm}$, Mugloto-type), and $0957(1.960 \mathrm{~mm}$, Mugloto-type).

UV-Vis-NIR Spectroscopy. Based on the different appearances of the two ruby types from Mozambique, a difference in their UV-Vis-NIR spectra is expected. To study these spectra, three samples were fabricated with windows perpendicular to the c-axis (see table 2). All the spectra are dominated by absorption due to chromium, characterized by bands around 410 and $560 \mathrm{~nm}$ (figure 22).

Maninge Nice sample no. 1702 shows a low shoulder at $330 \mathrm{~nm}$, which is believed to be caused by pairs of trivalent iron. The Mugloto sample (no. 0826) also has this feature, but it is much stronger, so much so that it does not appear as a shoulder but as a cutoff. This is indicative of a much higher iron content, which also causes features at 377, 388, and $450 \mathrm{~nm}$ (Ferguson and Fielding, 1971, 1972). The third spectrum is from Mugloto sample no. 0957, which shows a subtle blue component. It differs from the other $\mathrm{Mu}$ gloto sample by a minor shift of the $560 \mathrm{~nm}$ band and a slight increase of absorption over $600 \mathrm{~nm}$, alterations caused by the presence of an $\mathrm{Fe}^{2+}-\mathrm{Ti}^{4+}$ charge transfer.

Many Mugloto-type stones show this subtle color alteration, which can be removed by heat treatment (Pardieu et al., 2015; Sripoonjan et al., 2016; Saeseaw et al., 2018).

Treatments. Gems are often treated to improve their appearance, and Mozambican ruby is no exception. These gems commonly receive treatment to enhance their clarity and color. We distinguish two types of Mozambican ruby, which each have their own characteristics that can be improved by treatment. The most common treatments of Mozambican rubies are discussed below.

Flux Healing of Maninge Nice-Type Ruby. As discussed before, Maninge Nice-type rubies have a fine color but naturally occur as flat crystals with abundant fractures. These fractures will drastically reduce the durability of the gems. Heat treatment with the addition of flux (figure 23) can help heal the fractures and prevent the stones from breaking along these weak zones (Hänni, 1997-1998; Hughes and Galibert, 1998; Emmett, 1999; Pardieu et al., 2010). In this process, the stone is coated in a flux (usually borax) before heating. During heating, the flux will melt and flow into fissures. Fluxes have the capacity to lower the melting point of solid materials. This means that corundum will start to melt where the flux is in contact with the corundum (i.e., in the fractures and on the surface). Upon cooling, the molten compounds start to recrystallize, effectively closing the fracture. During this process, droplets of flux become trapped in the healed fissure, which we observe as fingerprints (figure 24). Where this fingerprint reaches the surface of a cut stone, a line of small cavities is often visible (Hänni, 1997-1998).

These flux-healed fractures often differ in appearance from natural fingerprints and can be recognized by their thicker droplets and more weblike configuration.

Since this process is associated with heating at high temperatures, crystals often become altered and/or form expansion fractures. 
TABLE 2. Summary of trace-element concentrations in Mozambican ruby samples (in ppma) using LA-ICP-MS. ${ }^{\mathrm{a}}$

\begin{tabular}{|c|c|c|c|c|c|c|c|}
\hline $\begin{array}{l}\text { GIA sample no. } 1702 \\
\text { (Pink, } 1.163 \mathrm{~mm} \text { ) }\end{array}$ & Spot number & ${ }^{24} \mathrm{Mg}$ & ${ }^{47} \mathrm{Ti}$ & ${ }^{51} \mathrm{~V}$ & ${ }^{53} \mathrm{Cr}$ & ${ }^{57} \mathrm{Fe}$ & ${ }^{69} \mathrm{Ga}$ \\
\hline & 1 & 22 & bdl & 2 & 714 & 551 & 7 \\
\hline & 2 & 23 & 33 & 2 & 671 & 573 & 8 \\
\hline & 3 & 20 & 16 & 2 & 682 & 617 & 8 \\
\hline & 4 & 25 & 24 & 3 & 875 & 665 & 7 \\
\hline & 5 & 23 & bdl & 2 & 678 & 584 & 8 \\
\hline & 6 & 16 & 17 & 2 & 682 & 548 & 7 \\
\hline & 7 & 19 & 27 & 2 & 714 & 591 & 8 \\
\hline \multirow[t]{9}{*}{$\begin{array}{l}\text { GIA sample no. } 0826 \\
\text { (Red, } 2.808 \mathrm{~mm})\end{array}$} & Spot number & ${ }^{24} \mathrm{Mg}$ & ${ }^{47} \mathrm{Ti}$ & ${ }^{51} \mathrm{~V}$ & ${ }^{53} \mathrm{Cr}$ & ${ }^{57} \mathrm{Fe}$ & ${ }^{69} \mathrm{Ga}$ \\
\hline & 1 & 28 & 17 & 4 & 639 & 1504 & 9 \\
\hline & 2 & 27 & 16 & 4 & 635 & 1501 & 9 \\
\hline & 3 & 28 & 17 & 4 & 655 & 1493 & 9 \\
\hline & 4 & 32 & 17 & 4 & 635 & 1490 & 9 \\
\hline & 5 & 37 & 18 & 4 & 706 & 1519 & 9 \\
\hline & 6 & 50 & 18 & 4 & 749 & 1523 & 9 \\
\hline & 7 & 35 & 17 & 4 & 718 & 1515 & 10 \\
\hline & 8 & 39 & 17 & 4 & 745 & 1555 & 9 \\
\hline \multirow[t]{10}{*}{$\begin{array}{l}\text { GIA sample no. } 0957 \\
\text { (Purplish red, } 1.960 \mathrm{~mm} \text { ) }\end{array}$} & Spot number & ${ }^{24} \mathrm{Mg}$ & ${ }^{47} \mathrm{Ti}$ & ${ }^{51} \mathrm{~V}$ & ${ }^{53} \mathrm{Cr}$ & ${ }^{57} \mathrm{Fe}$ & ${ }^{69} \mathrm{Ga}$ \\
\hline & 1 & 12 & 14 & 4 & 788 & 1501 & 10 \\
\hline & 2 & 12 & 13 & 7 & 804 & 1563 & 10 \\
\hline & 3 & 12 & 16 & 5 & 824 & 1566 & 10 \\
\hline & 4 & 12 & 13 & 4 & 800 & 1566 & 10 \\
\hline & 5 & 12 & 13 & 4 & 796 & 1479 & 10 \\
\hline & 6 & 12 & 14 & 4 & 776 & 1493 & 10 \\
\hline & 7 & 12 & 14 & 4 & 796 & 1512 & 10 \\
\hline & 8 & 11 & 18 & 4 & 769 & 1457 & 10 \\
\hline & Detection limit & 0.12 & 0.3 & 0.03 & 0.37 & 3 & 0.01 \\
\hline
\end{tabular}

${ }^{a}$ All measurements were taken inside the circles indicated, which correspond to the area that was analyzed during UV-Vis-NIR spectroscopy (see figure 22).

Sometimes the fractures are simply filled with a glass that has a high lead content. In this case, the fractures are not healed and the glass can be easily removed with acids to expose the fractures again. Depending on the type of glass used, this process can be done at temperatures below $1000^{\circ} \mathrm{C}$, which does not alter most inclusions. However, the glass filling is very characteristic, containing an abundance of bubbles, and it often has a characteristic colored flash under the microscope (figure 25). The lower durability of the glass also creates a luster difference with the corundum host (Pardieu, 2005; McClure et al., 2006; Pardieu et al., 2010; Scarratt, 2012).
Both of these treatments are associated with elevated temperatures that can alter natural inclusions as well. One of the most obvious telltale signs is expansion fractures around crystals. The opaque black inclusions commonly seen in Maninge Nice-type rubies are very susceptible to this and often appear as black discs after heat treatment (figure 26).

Low-Temperature Heat Treatment of Mugloto-Type Ruby. Rubies from Mugloto that have a dark color or strong blue color patches will be heat treated without any added chemicals to lighten their color (figure 27). In recent years, heat treaters have become very 
A. Before heat treatment

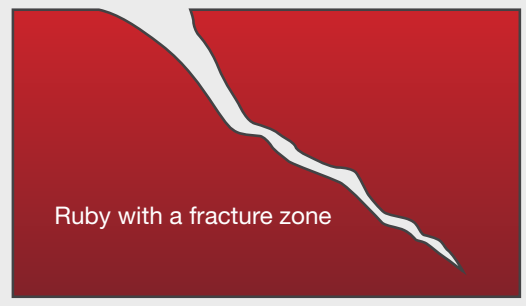

D. After possible devitrification

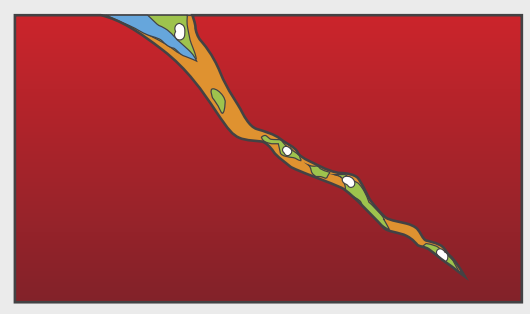

B. During heating process

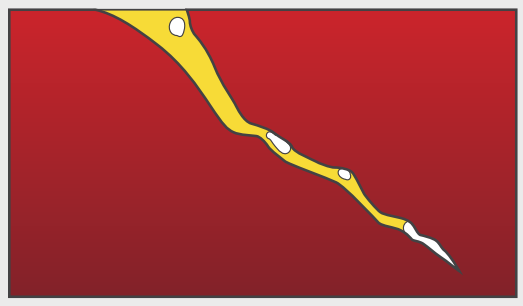

E. After cleaning by surface-etching

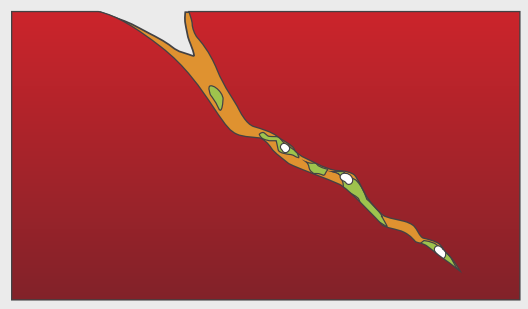

C. After cooling

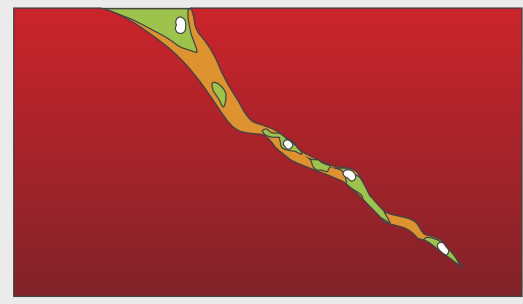

Ruby (corundum)

Recrystallized ruby (synthetic ruby)

Low-viscose glass melt

Solidified glass

Devitrified glass (glass exsolutions)

Trapped flux

Figure 23. These images (from Hänni, 1997-1998) show the process of heat treatment with flux. During heating (step B), the flux flows into the fractures. When the temperature is raised further, the corundum near the fracture starts to melt. After cooling (step C), the mix of molten flux and corundum recrystallizes and "heals" the fracture. Bubbles of flux are trapped in the healing corundum, forming fingerprints.

skilled at this process, ever lowering the temperatures. These temperatures are low enough that inclusions are not severely altered. Below temperatures of

Figure 24. Flux-healed fracture in a ruby that was heated with borax flux. Photo by C. Khowpong; field of view $1.75 \mathrm{~mm}$. Darkfield illumination.

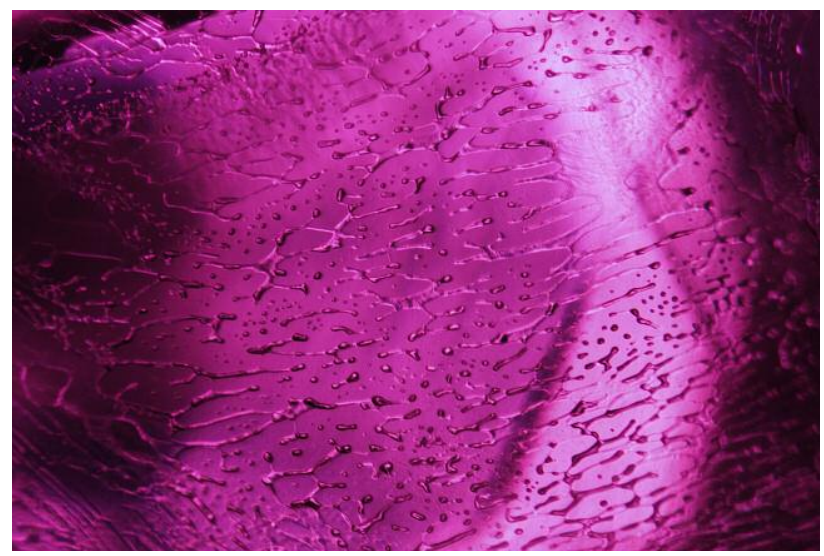

$1200^{\circ} \mathrm{C}$, even rutile silk is not dissolved into the lattice. GIA has conducted several studies of Mozam-

Figure 25. Glass-filled fractures with bubbles and blue flashes are the most obvious features in this glass-filled ruby, but natural inclusions such as bands of silk can also be seen. Photo by C. Khowpong; field of view $4.60 \mathrm{~mm}$. Darkfield illumination.

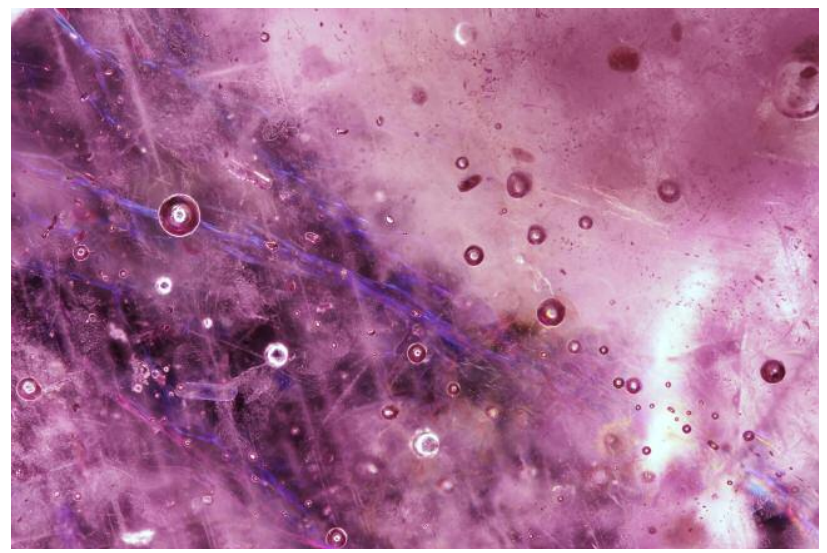




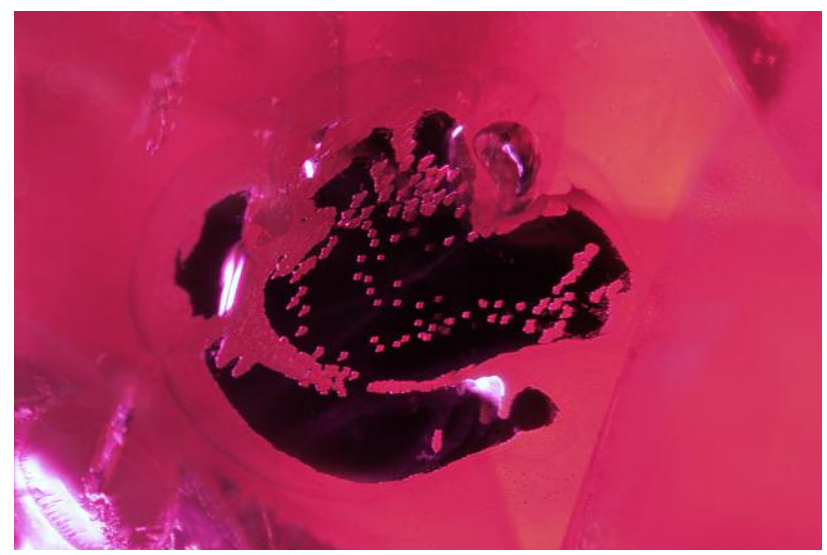

Figure 26. This opaque black inclusion expanded during heat treatment, creating a fracture around it. The molten crystal flowed into the fracture and solidified upon cooling, creating an opaque black disc. This is sometimes referred to as "bleeding out" of a crystal. Photo by C. Khowpong; field of view $1.20 \mathrm{~mm}$. Darkfield illumination.

bican ruby treatment to determine the extent and detectability of heating at lower temperatures (Pardieu et al., 2015; Saeseaw et al., 2018). An initial experiment was done under unknown conditions by a professional offering his services to the trade; all follow-up experiments were carried out by GIA under known circumstances. Temperatures varied from $600^{\circ} \mathrm{C}$ to $900^{\circ} \mathrm{C}$ and heating times from 160 minutes to 24 hours. During all these experiments, the stones were fully documented before and after treatment, and some were treated multiple times. Identification of low-temperature heat treatment re- quires inclusion study and FTIR spectroscopy (Pardieu et al., 2015; Saeseaw et al., 2018).

The reaction of crystal inclusions to heat treatment is unpredictable. In some cases, the crystals caused expansion fractures, while others did not change even when heated at more extreme conditions. Platelets can start to develop bright spots when heated at temperatures over $700^{\circ} \mathrm{C}$ (figure 28). It is important to note that this is not always seen after treatment, so the absence of spotted platelets does not conclusively indicate the absence of treatment. The platelets never showed alteration at $600^{\circ} \mathrm{C}$, but under the conditions of this experiment the stone's color was not altered (Saeseaw et al., 2018). Fractures with iron staining showed a change from yellowish to brownish red, even when heated at low temperatures (Sripoonjan et al., 2016). However, these features are not commonly seen in faceted stones.

When the inclusion scene does not provide conclusive evidence of treatment, infrared spectroscopy can offer an indication of heating. In the majority of cases, minerals with an $\mathrm{OH}$ group such as boehmite and kaolinite are affected by heat treatment, so their presence in the FTIR spectrum indicates the absence of heating. By far the most common feature seen in the Mozambican rubies is a peak at $3309 \mathrm{~cm}^{-1}$. Upon heating, the intensity of this peak always diminishes. When the peak before heating is strong enough, peaks at 3232 and $3185 \mathrm{~cm}^{-1}$ are formed (figure 29) (Pardieu et al., 2015; Saeseaw et al., 2018). Often called the 3309 series, this has only been observed in Mozambican rubies after heat treatment. Rubies with a weaker 3309 peak will not develop a

Figure 27. Left: An untreated Mugloto-type ruby clearly showing blue zones when viewed perpendicular to the caxis. Right: The stone after heat treatment for 160 minutes at $800^{\circ} \mathrm{C}$. Photos by S. Engniwat.

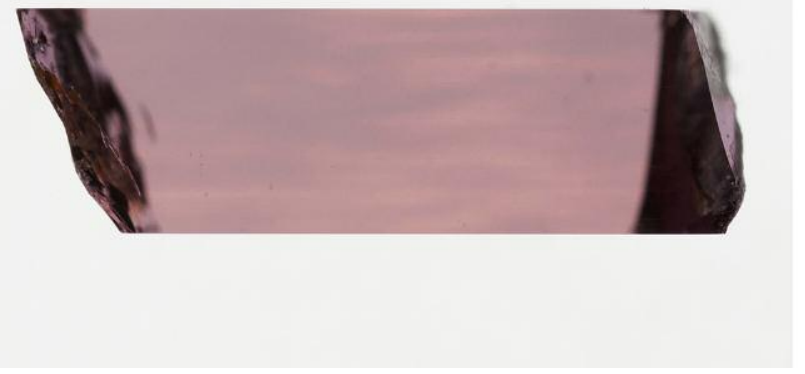



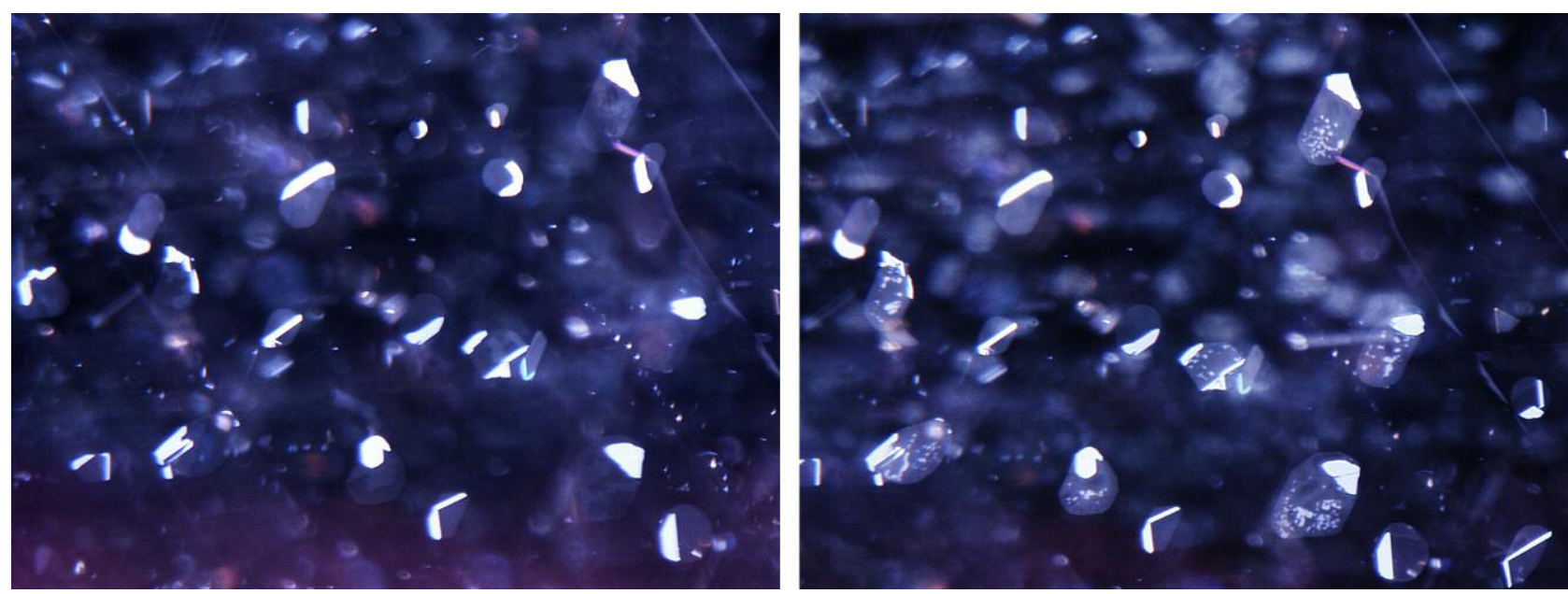

Figure 28. Left: Platelets in an unheated Mozambican ruby. Right: The platelets developed a spotted appearance after heat treatment at $900^{\circ} \mathrm{C}$ for 160 minutes. Photos by GIA; field of view $1.30 \mathrm{~mm}$. Fiber-optic illumination.

3309 series after heating, so the absence of this series is not conclusive evidence of the absence of treatment (figure 30) (Saeseaw et al., 2018).

Distinguishing Rubies from Mozambique. Based on gemological data, Mozambican rubies can often be clearly distinguished. Many other ruby sources have a very different geological history, such as the marble-hosted deposits (e.g., Mogok and Mong Hsu in Myanmar, Luc Yen in Vietnam, and Jegdalek in Afghanistan) or the basalt-hosted deposits (Thailand-

Figure 29. FTIR spectrum of a Mozambican ruby showing a strong $3309 \mathrm{~cm}^{-1}$ peak in its unheated state (blue trace). The other spectrum (red trace) was taken after heating at $800^{\circ} \mathrm{C}$ for 160 minutes and clearly shows the development of 3232 and $3185 \mathrm{~cm}^{-1}$ peaks and a decrease in $3309 \mathrm{~cm}^{-1}$ peak intensity.

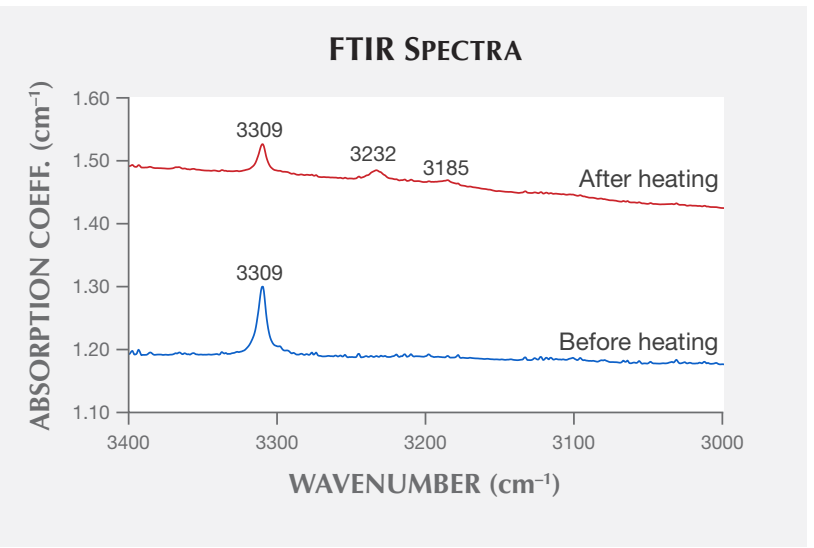

Cambodia). These have very different inclusion scenes, allowing for a clear separation. Rubies from both of these geological origins usually have a more extreme reaction under UV light than Mozambican rubies, with marble-hosted rubies often being more fluorescent, especially under short-wave UV, and basalt-related stones being almost inert.

With rubies from other amphibole-related deposits such as those found in northeastern Madagascar (Didy, Andilamena, Zahamena, and Vatomandry) and Tanzania (Longido and Winza), the separation is

Figure 30. The FTIR spectrum of a Mozambican ruby (blue trace) shows a weak $3309 \mathrm{~cm}^{-1}$ peak in its unheated state. The red trace, obtained after heating at $800^{\circ} \mathrm{C}$ for 160 minutes, shows a decrease in peak intensity but no formation of a 3309 series.

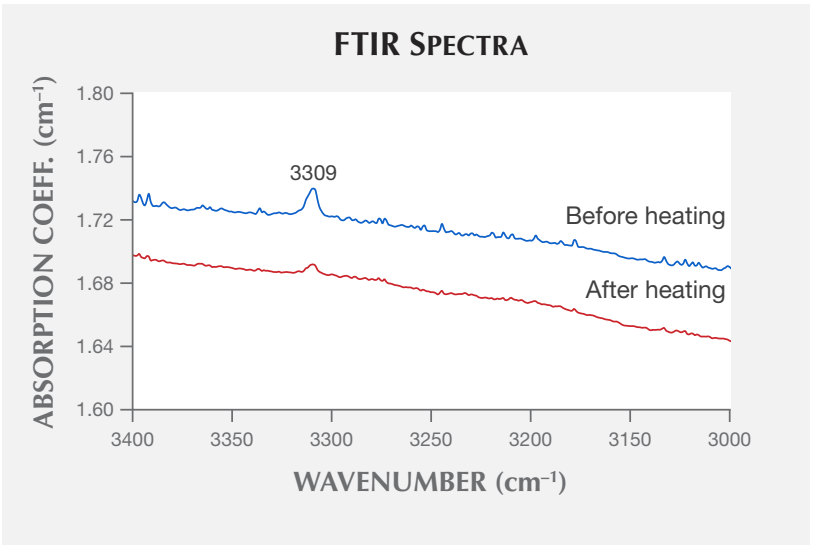




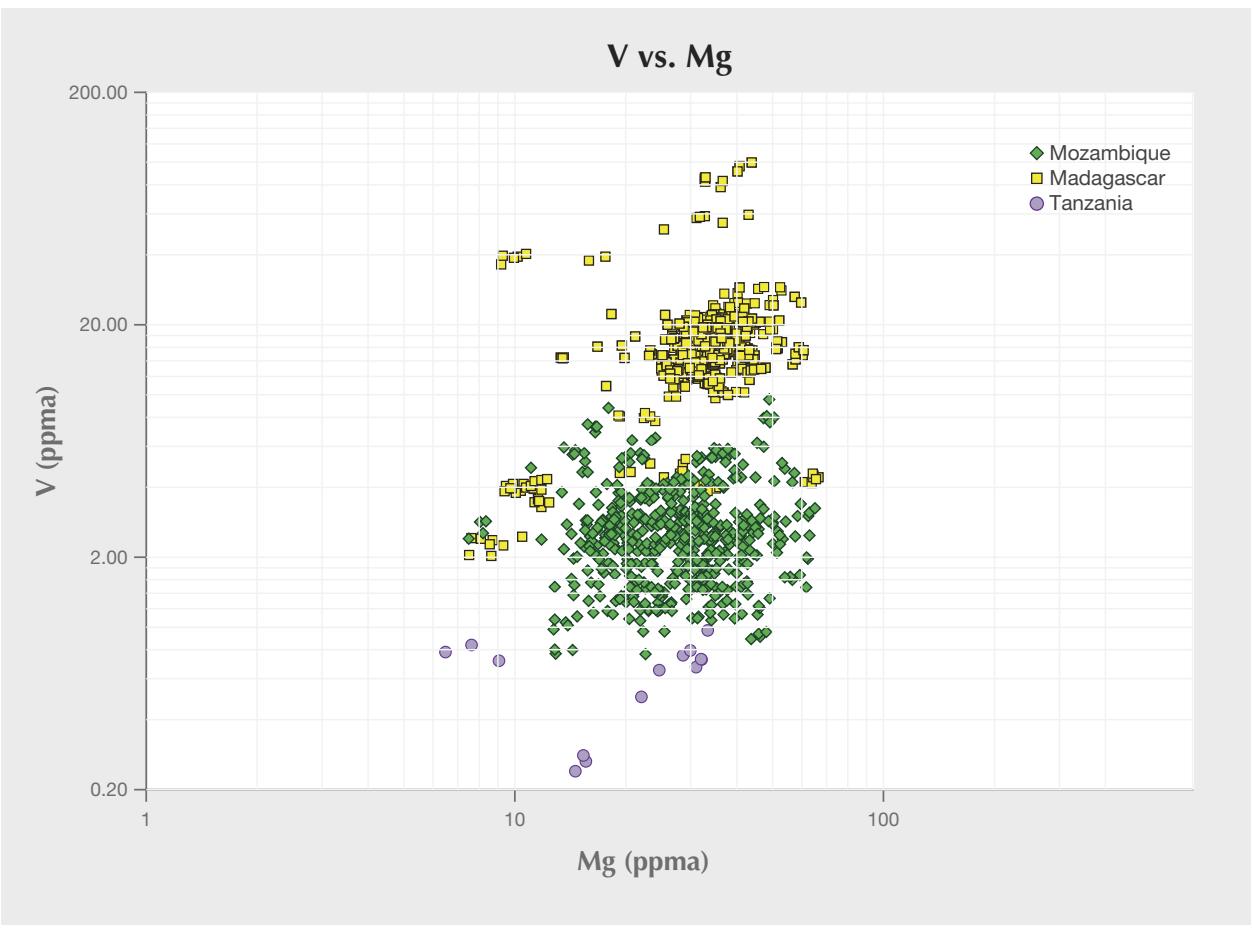

Figure 31. Traceelement chemistry plot of $V$ vs. $M g$ (ppma, measured by LA-ICPMS) following GIA protocols outlined in Saeseaw et al. (2018) for rubies from Mozambique, Madagascar, and Tanzania.

more challenging. All show a slightly similar inclusion scene and share the same gemological characteristics such as color intensity and UV reaction.

Trace-element chemistry can provide indications for origin discrimination between the East African ruby deposits in Mozambique, Madagascar, and Tanzania (figure 31). Vanadium content is often lower in rubies from the Winza deposit in Tanzania and higher in those from Madagascar, although some deposits yield $\mathrm{V}$ concentrations that overlap with Mozambican rubies.

\section{CONCLUSIONS}

GIA has been privileged to follow this discovery from the start and document its growth during the last decade. This work has shown that there are two varieties of Mozambican ruby: (1) Maninge Nice-type, characterized by strong color and fluorescence, a flatter shape, and abundant inclusions; and (2) Muglototype, with its weaker UV reaction but cleaner and bulkier stones.

In ten years, treatments of Mozambican rubies have evolved considerably, from copying existing recipes that worked with similar material, such as flux healing and glass filling, to adapting procedures of low-temperature heat treatment to specific Mozambican stones.

The first decade of Mozambican rubies from Montepuez was characterized by chaotic development and plenty of opportunities (figures 32 and 33). New deposits were found, large crowds of garimpeiros dug up rubies, and foreign buyers operated from the shadows, all while a formal framework was being developed. Initially this caused a series of conflicts in the heat of the rush. The arrival of large companies disrupted the first equilibrium between miners, buyers, and local authorities. By now, a delicate balance has been

Figure 32. The $40.23 \mathrm{ct}$ Rhino ruby was sold at a December 2014 Gemfields auction in Singapore. Photo by Robert Weldon.

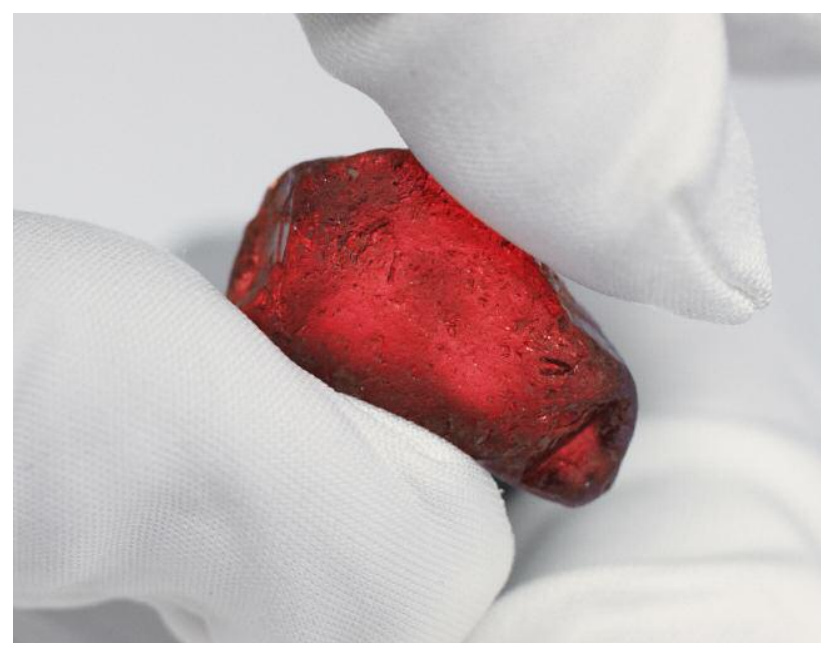




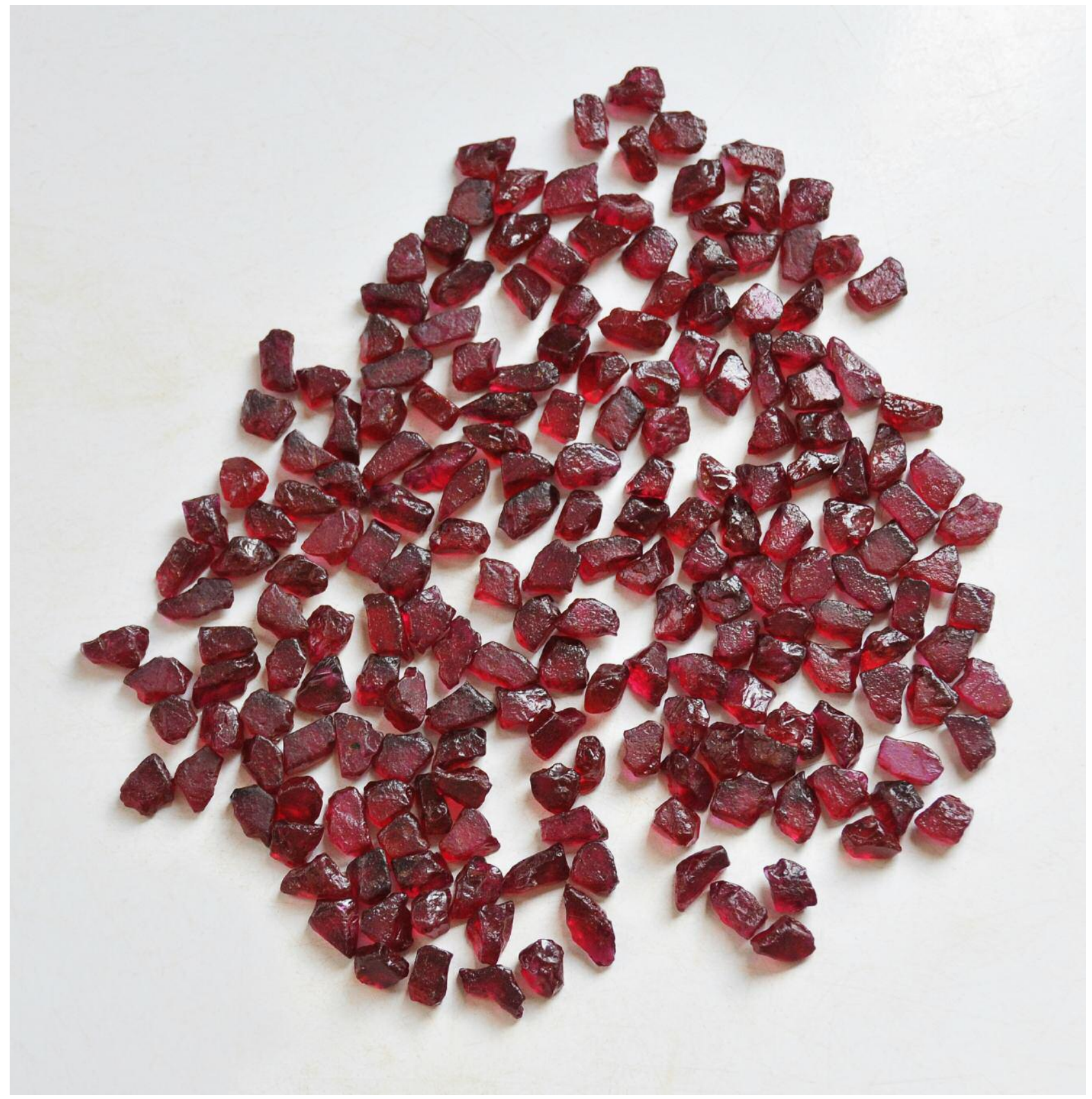

Figure 33. In terms of value, fine Mugloto-type rubies are the most important stones being mined in the Montepuez area. Their desirable color, high clarity, and blocky shape often yield attractive stones that are in high demand. Photo by Vincent Pardieu/GIA.

reestablished. At the moment, both MRM and the artisanal miners contribute significant amounts of ruby to the trade although the amount of ruby mined by the garimpeiros is decreasing.

Looking back on our initial experiences with Mozambican rubies, it is safe to say that this discovery will have a long-lasting impact on the ruby trade and perhaps the colored stone trade as a whole. Never have so many rubies, in such a wide range of sizes and qualities, come out of the ground and into the market. Ruby is becoming more accessible than ever. This is disrupting the established market practices of secrecy and low transparency, creating some resistance from conservative (or nostalgic) dealers. However the Montepuez deposits evolve, this is already proving to be one of the most exciting ruby sources ever discovered. 
ABOUT THE AUTHORS

Mr. Vertriest is supervisor of field gemology, and Ms. Saeseaw is senior manager of identification, at GIA in Bangkok.

\section{ACKNOWLEDGMENTS}

The authors would like to thank all miners, both large companies and small-scale artisanal garimpeiros, that hosted and assisted GIA at the ruby mines around Montepuez. GIA's former field gemologist, Vincent Pardieu, organized multiple expeditions to the ruby mining areas in Mozambique to collect samples and document the situation on the ground; his reports were very valuable to summarize the evolution of the Montepuez deposit. The majority of data (spectroscopy, chemistry, and photomicrography) presented in this article was collected by Ungkhana Atikarnsakul and Charuwan Khowpong, analyst technicians at GIA's Bangkok lab.

\section{REFERENCES}

Beran A., Rossman G.R. (2006) OH in naturally occurring corundum. European Journal of Mineralogy, Vol. 18, No. 4, pp. 441447, http://dx.doi.org/10.1127/0935-1221/2006/0018-0441

Bingen B., Jacobs J., Viola G., Henderson I.H.C., Skår Ø., Boyd R., Thomas R.J., Solli A., Key R.M., Daudi E.X.F. (2009) Geochronology of the Precambrian crust in the Mozambique Belt in NE Mozambique, and implications for Gondwana assembly. Precambrian Research, Vol. 170, No. 3-4, pp. 231-255, http://dx.doi.org/10.1016/j.precamres.2009.01.005

Boyd R., Nordgulen Ø., Thomas R.J., Bingen B., Bjerkgård T., Grenne T., Henderson I., Melezhik V.A., Often M., Sandstad J.S., Solli A., Tveten E., Viola G., Key R.M., Smith R.A., Gonzalez E., Hollick L.J., Jacobs J., Jamal D., Motuza G., Bauer W., Daudi E., Feitio P., Manhica V., Moniz A., Rosse D. (2010) The geology and geochemistry of the East African orogen in northeastern Mozambique. South African Journal of Geology, Vol. 113, No. 1, pp. 87-129, http://dx.doi.org/10.2113/gssaig.113.1.87

Chapin M., Pardieu V., Lucas A. (2014) Mozambique: A ruby discovery for the 21 st century. $G \uplus G$, Vol. 51, No. 1, pp. 44-54, http://dx.doi.org/10.5741/GEMS.51.1.44

Emmett J.L. (1999) Fluxes and the heat treatment of ruby and sapphire. $G \uplus G$, Vol. 35, No. 3, pp. 90-92.

Ferguson J., Fielding P.E. (1971) The origins of the colours of yellow, green and blue sapphires. Chemical Physics Letters, Vol. 10, No. 3, pp. 262-265, http://dx.doi.org/10.1016/0009$2614(71) 80282-8$

- (1972) The origins of the colours of natural yellow, blue, and green sapphires. Australian Journal of Chemistry, Vol. 25, No. 7, pp. 1371-1385, http://dx.doi.org/10.1071/CH9721371

Gemfields (2019) Gemfields press release, Jan. 29, https://mining.com/wp-content/uploads/2019/01/gemfieldspress-announcement-jan29-2019.pdf, January 29.

GIT Gem Testing Laboratory (2009) Some characteristics of "Mozambique" ruby, Nov. 19, https://www.git.or.th/eng/ testing_center_en/lab_notes_en/glab_en/2009/GIT_article_rub y_mozambique_web.pdf, November 19 .

Grantham G.H., Macey P.H., Ingram B.A., Roberts M.P., Armstrong R.A., Hokada T., Shiraishi K., Jackson C., Bisnath A., Manhica V. (2008) Terrane correlation between Antarctica, Mozambique and Sri Lanka: Comparisons of geochronology, lithology, structure and metamorphism and possible implications for the geology of southern Africa and Antarctica. Geological Society of London, Special Publication, Vol. 308, No. 1, pp. 91-119, http://dx.doi.org/10.1144/SP308.4

Hänni H.A. (1997-1998) Short notes on some gemstone treatments. Journal of the Gemmological Association of Hong Kong, Vol. 20, pp. 44-52.

Hänni H.A., Krzemnicki M.S. (2009) Das neue Rubinvorkommen von Montepuez, Mosambik (The new ruby deposit of Montepuez, Mozambique). Zeitschrift der Deutschen Gemmologischen Gesellschaft, Vol. 58, No. 3-4, pp. 127-130.
Hsu T., Lucas A., Pardieu V. (2014) Mozambique: A ruby discovery for the 21 st century. GIA Research News, https://www.gia.edu/ gia-news-research-mozambique-expedition-ruby-discoverynew-millennium

Hughes R.W. (2015) Red rain: Mozambique ruby pours into the market. http://www.lotusgemology.com/index.php/library/ articles/316-red-rain-mozambique-ruby-pours-into-the-market

Hughes R.W., Galibert O. (1998) Foreign affairs: Fracture healing/filling of Möng Hsu ruby. Australian Gemmologist, Vol. 20, No. 2, pp. 70-74.

Hughes R.W., Manorotkul W., Hughes E.B. (2017) Ruby Æ) Sapphire: A Gemologist's Guide. RWH Publishing/Lotus Publishing, Bangkok.

Koivula J.I., Kammerling R.C. (1991) Gem News: Update on corundum. $G \uplus G$, Vol. 27, No. 1, p. 48.

Lächelt S. (2004) The geology and mineral resources of Mozambique. Maputo: Républica de Moçambique, Monostério dos Recursos Minerais e Energia, Direcçâo Nacional de Geologia.

Laurs B.M., Zwaan J.C., Breeding C.M., Simmons W.B., Beaton D., Rijsdijk K.F., Befi R., Falster A.U. (2008) Copper-bearing (Paraíba-type) tourmaline from Mozambique. Gせ) G, Vol. 44, No. 1, pp. 4-30, http://dx.doi.org/10.5741/GEMS.44.1.4

Lucas A., Hsu T. (2017) Gem News International: New ruby miner in Mozambique. GやG, Vol. 53, No. 1, p. 121.

Lucas A., Pardieu V. (2014) Gemfields inaugural rough ruby auction in Singapore. GIA Research News, July 17, https://www.gia.edu/ gia-news-research-gemfields-ruby-auction-singapore

McClure S.F., Koivula J.I. (2009) Gem News International: Preliminary observations on new rubies from Mozambique. $G \uplus G$, Vol. 45, No. 3, pp. 224-225.

McClure S.F., Smith C.P., Wang W., Hall M. (2006) Identification and durability of lead glass-filled rubies. $G \uplus G$, Vol. 42 , No. 1, pp. 22-34, http://dx.doi.org/10.5741/GEMS.42.1.22

Mustang Resources realises maiden ruby sales from new Thailand office (2018) Mining Review Africa, https://www.miningreview.com/diamonds-gems/mustang-resources-realises-maidenruby-sales-from-new-thailand-office, April 11.

Pardieu V. (2005) Lead glass filled/repaired rubies. www.aigs laboratory.com/Filearticle/55.pdf, Jan. 17

Pardieu V. (2017) Gem News International: Update on Mozambique ruby mining and trading. $G \oplus G$, Vol. 53, No. 3, pp. 377-380.

Pardieu V. (2018) Tough lessons from Mustang's maiden ruby auction. InColor, No. 37, pp. 58-61.

Pardieu V., Chauviré B. (2012) Gem News International: Update on ruby mining and trading in northern Mozambique. $G \oplus G$, Vol. 48, No. 4, pp. 309-311.

Pardieu V., Jacquat S., Senoble J.B., Bryl L.P., Hughes R.W., Smith M. (2009a) Expedition report to the ruby mining sites in northern Mozambique (Niassa and Cabo Delgado provinces). GIA Research News, Dec. 23, https://www.gia.edu/gia-news-researchnr121709 
Pardieu V., Thanachakaphad J., Jacquat S., Senoble J.B., Bryl L.P. (2009b) Rubies from the Niassa and Cabo Delgado regions of northern Mozambique. GIA Research News, Sept. 13, https://www.gia.edu/gia-rubies-from-niassa-cabo-delgado

Pardieu V., Sturman N., Saeseaw S., Du Toit G., Thirangoon K. (2010) FAPFH/GFF treated ruby from Mozambique: A preliminary report. GIA Research News, May 11, https://www.gia.edu/ gia-news-research-nr51110

Pardieu V., Sangsawong S., Muyal J., Chauviré B., Massi L., Sturman N. (2013) Rubies from the Montepuez area. GIA Research News, Oct. 1, https://www.gia.edu/gia-rubies-from-montepuezarea

Pardieu V., Saeseaw S., Detroyat S., Raynaud V., Sangsawong S., Bhusrisom T., Engniwat S., Muyal J. (2015) GIA reports on lowtemperature heat treatment of Mozambique ruby. GIA Research News, April 28, https://www.gia.edu/gia-news-research-lowtemperature-heat-treatment-mozambique-ruby

Rondeau B., Delaunay A. (2007) Les tourmalines cuprifères du Nigeria et du Mozambique. Revue de Gemmologie a.f.g., No. 160 , pp. 8-13.

Saeseaw S., Kongsomart B., Atikarnsakul U., Khowpong C., Vertriest W., Soonthorntantikul W. (2018) Update on "low-temperature" heat treatment of Mozambican ruby: A focus on inclusions and FTIR spectroscopy. GIA Research News, Apr. 30, https:/www.gia.edu/ongoing-research/update-low-temperatureheat-treatment-mozambican-ruby-focus-on-inclusions-andftir-spectroscopy

Sangsawong S., Pardieu V., Raynaud V. (2016) Gem News Interna- tional: Purple pyrope-almandine garnet from Mozambique $G \uplus G$, Vol. 52, No. 3, pp. 321-323.

Scarratt K. (2012) A discussion on ruby-glass composites \& their potential impact on the nomenclature in use for fracture-filled or clarity enhanced stones in general. Feb. 3, http://www.gia thai.net/pdf/Ruby-Glass_Composites.pdf

Shigley J.E., Laurs B.M., Janse A.J.A., Elen S., Dirlam D.M. (2010) Gem localities of the 2000s. Ge G, Vol. 46, No. 3, pp. 188-217, http://dx.doi.org/10.5741/GEMS.46.3.188

Shor R., Weldon R. (2015) Gemfields bets on gemstone market's growth. GIA Research News, Jan. 26, https://www.gia.edu/gianews-research-gemfields-bets-gemstone-markets-growth

Simonet C. (2018) The Montepuez ruby deposits, what's next? InColor, No. 37, pp. 32-40.

Smith C.P. (1995) A contribution to understanding the infrared spectra of rubies from Mong Hsu, Myanmar. Journal of Gemmology, Vol. 24, No. 5, pp. 321-335.

Sripoonjan T., Wanthanachaisaeng B., Leelawatanasuk T. (2016) Phase transformation of epigenetic iron staining: Indication of low-temperature heat treatment in Mozambique ruby. Journal of Gemmology, Vol. 35, No. 2, pp. 156-161.

Valoi E., Macrae C. (2015) Mozambique's gem wars. Al Jazeera, Africa Investigates, Dec. 10, https://www.aljazeera.com/programmes/africainvestigates/2015/12/mozambique-gem-wars151210075320384.html

Vertriest W., Pardieu V. (2016) Update on gemstone mining in northern Mozambique. GÆG, Vol. 52, No. 4, pp. 404-409, http://dx.doi.org/10.5741/GEMS.52.4.404

For online access to all issues of GEMS \& GEMOLOGY from 1934 to the present, visit: 